\title{
EU economic integration agreements, Brexit and trade
}

\author{
Marie M. Stack ${ }^{1}$ (D) Martin Bliss ${ }^{2}$
}

Published online: 2 May 2020

(c) Kiel Institute 2020

\begin{abstract}
The effects of regionalism on trade have been extensively evaluated within a gravity model framework. With the expected exit of the United Kingdom (UK) from the European Union (EU), the prospect of regional disintegration has brought about a new impetus to studying trade policy effects. Using actual and forecast data for a panel of bilateral imports between the EU15 and the rest of the world, this paper examines the trade effects of EU economic integration agreements (EIAs), their evolution over time and the related counterfactual Brexit trade policy scenarios. Distinct trade effects are obtained for the EU trade related agreements; positive, significant and of similar magnitude for the EU and free trade agreement (FTA) coefficients, but negative and significant (and smaller in magnitude) for the regional economic partnership agreements (EPAs). The subperiod results suggest the positive coefficients of EU and FTA membership tend to diminish over time, implying earlier membership of EIAs came with greater trade benefits. Finally, in generating the predicted values for the trade effects of three alternative counterfactual Brexit scenarios (hard Brexit, hard Brexit plus, global Britain), the findings suggest an asymmetric effect depending on the perspective of the UK versus the EU. Whereas the UK's trade would decline substantially with all three country groups (the EU, the FTAs and regional EPAs) and rise substantially with the rest of the world, only minor percentage changes are predicted for EU bilateral trade.
\end{abstract}

Keywords Gravity model · Trade policy · Brexit

JEL Classification F14 $\cdot$ F15 $\cdot$ C23

Marie M. Stack

Marie.Stack@ntu.ac.uk

1 Nottingham Trent University, Nottingham NG1 4BU, UK

2 Loughborough University, Loughborough LE11 3TU, UK 


\section{Introduction}

The proliferation of regional trade agreements (RTAs) since the 1990s has prompted much interest in studying the trade effects of regional integration. According to the WTO (2018), some 287 RTAs are in force (as of 1 May 2018), corresponding to 459 notifications from World Trade Organisation (WTO) members. Studies of the trade effects of economic integration agreements (EIAs) most commonly include regional integration in Europe, mainly because the European Union (EU) represents the deepest and most durable RTA worldwide and its succession of enlargements provides the basis for continual study (Greenaway and Milner 2002).

Most studies of regional integration in Europe find a small, positive and significant effect of RTAs on trade although a neutral or even a negative effect also feature among the empirical findings. Using the gravity model framework, early studies tend to use cross sectional methods or a series of cross sections to assess the importance of regional integration whereas panel methods dominate more recent studies. Aitken (1973), for example, estimate the gravity model as a cross section for each year over the period 1951-1967; the trade effects for the dummy variables denoting the European Economic Community (EEC) and the European Free Trade Association (EFTA) are found to be consistent with theoretical predictions. In other words, the trade preference coefficients are initially negative and insignificant in the preintegration period, change sign during the integration phase and increase in magnitude with the progression of time, eventually becoming positive and significant. Continuing with the theme of estimating the trade effects of the EEC and EFTA dummies among the industrialised countries, Bayoumi and Eichengreen (1998) analyse successive cross sections for the later period, 1956-1992, to identify differences over time in the trade creating and trade diverting effects of European regionalism. The effect of European regional integration has also been examined across a range of panel estimators (Bussière et al. 2005; Stack 2009) while Cheng and Wall (2005) extend the sample size to consider the trade effects of additional regional blocks.

The trend of EU enlargement, however, is set to reverse with the contraction of EU membership to 27 countries as a consequence of the June 2016 referendum to withdraw the UK from the EU. ${ }^{1}$ Not surprisingly, the unprecedented withdrawal of a large country from the world's largest trading block has prompted much empirical interest. $^{2}$

Much of the existing literature on estimating the trade consequences of Britain's exit from the EU (i.e. Brexit) relies on the World Input Output Database (WIOD),

\footnotetext{
${ }^{1}$ Formally, the UK was expected to leave the EU on 29 March 2019, two years after the British government triggered Article 50, notifying the EU of its intention to end EU membership. Since then, the UK and the EU have negotiated three extensions: initially for two weeks (until 10 April 2019) and then for six months (until 31 October 2019) to allow the UK Parliament to ratify the Withdrawal Agreement. The latest extension (until 31 January 2020) was triggered by the Benn Act, which required the Prime Minister to seek a further extension if a deal was not agreed by 19 October 2019. Note that the analysis is conducted to coincide with the original planned exit date.

2 Although the EU has experienced territorial reductions with the exit of Algeria in 1962 upon independence and the exit of Greenland in 1985, no country has previously terminated EU membership.
} 
see, for example, Van Reenen (2016); Brakman et al. (2018); Dhingra et al. (2017); Felbermayr et al. (2018). In effect, the data facilitate a quantitative trade model of the global economy, allowing for the channels through which trade affects consumers, firms and workers, thereby providing a map from trade to welfare analysis (Van Reenen 2016). ${ }^{3}$ In other strands of the literature, Kee and Nicita (2017) construct an overall trade restrictiveness index of the UK's major trading partners to analyse the short term effects of Brexit on goods trade. For a selection of EU and non EU trading partner countries, Douch et al. (2018) use a synthetic control method to analyse the effects of Brexit on UK bilateral trade. Various post Brexit trade policy scenarios have also been quantified using bilateral trade data that is inherent to the gravity model framework (HM Treasury 2016; Oberhofer and Pfaffermayr 2018). ${ }^{4}$

For a comprehensive panel dataset of bilateral imports between the 15 established member countries of the EU and the rest of the world, this paper examines the trade effects of EU economic integration agreements (EIAs), their evolution over time and the related counterfactual trade policy scenarios arising post Brexit.

Three distinguishing features characterise this paper. First, in contrast to the existing literature that tend to use a smaller sample of countries and hence a more limited number of EU trade related agreements, the trade effects for the full listing of EU EIAs are estimated. Specifically, EU EIAs comprise membership of the EU, an economic and political partnership between 28 countries; various trade related agreements including customs unions, free trade agreements (FTAs), association agreements and stabilisation agreements with 38 countries; and the more recently formed (and ongoing negotiation of) trade and development economic partnership agreements (EPAs) with 28 countries (see the Appendix Table 6 for the full list of EU EIAs). ${ }^{5}$

Second, on the assumption that export growth projections for the trading partner countries apply equally across all the EU15 countries, forecast values are calculated for bilateral imports over the period 2017-2022. In essence, the sample period includes actual data (1960-2016) and forecast data (2017-2022). The benefits of forward looking data are twofold. First, it allows for estimation of the trade effects of economic integration associated with recently formed trade agreements, for example, the trade agreement between the EU and Canada that came into effect in September 2017. Second, the trade effects of economic disintegration associated with the planned exit of the UK from the EU can also be estimated. In other words, the potential trade effects of Brexit coincide with the planned date of departure in contrast to the existing literature that conduct counterfactual trade policy scenarios on time scales before Brexit actually occurs.

\footnotetext{
3 Note that the WIOD data comprise mostly developed countries only. Among the drawbacks of WIOD, Oberhofer and Pfaffermayr (2018) note that the limited time variation of policy indicators makes it difficult to identify the causal effects of RTAs.

4 Taking a broader perspective, Kierzenkowski et al. (2016) go beyond the effects of Brexit on trade to analyse the near term and longer term effects of Brexit on the wider economy, including trade, foreign direct investment, immigration and skills.

5 See Limão (2016) for an in depth review of the effects of preferential trade agreements.
} 
Third, using the gravity model framework, the analysis is undertaken controlling for two potential sources of endogeneity bias, namely omitted variable bias and simultaneity bias. In estimating the gravity model specification as a 2SLS regression with country fixed effects, the possibility that trade and EIAs are simultaneously determined - an issue often overlooked in the empirical literature - is taken into account. Specifically, geographic variables, namely joint land area and joint continents, are used as instrumental variables in the 2SLS regression to represent the potentially endogenous EU trade related agreements.

The findings confirm the trade enhancing effect of economic integration. Distinct trade effects, however, are obtained when the EU trade related agreements are split according to the type of arrangement: positive, significant and of similar magnitude for EU membership and the FTAs, but negative and significant (and smaller in magnitude) for the regional EPAs. The mixed results for the trade policy effects largely depend on the degree of liberalisation and the concomitant reduction of tariff and non tariff barriers.

Furthermore, the subperiod results suggest the positive coefficients of EU and FTA membership tend to diminish over time, implying earlier membership of EIAs came with greater trade benefits associated with the 'four freedoms' of the Single Market. After the fallout of the global financial crisis, its aftermath and the debt crisis in Europe, the forecast subperiod suggests a rebound in the trade effect of EU membership.

Finally, in generating the predicted values for the trade effects of three alternative counterfactual Brexit scenarios (hard Brexit, hard Brexit plus, global Britain), the findings suggest the UK's trade with all three country groups (the EU, the FTAs and regional EPAs) would decline substantially, approximately by one-third. On the other hand, trade with the rest of the world would rise by nearly a half. In aggregate, UK bilateral trade with all countries would decline by $6 \%$ and $13 \%$ under the hard Brexit and the hard Brexit plus scenarios respectively, but these losses would be partially offset by the global Britain strategy (5\%). The global Britain strategy, however, comes with major caveats. From the EU's perspective, only minor percentage changes in bilateral trade are predicted under all three scenarios, suggesting an asymmetry of effect.

The remainder of the paper is structured as follows. Section 2 presents the gravity model specification of bilateral trade and the estimation strategy. The data definitions and sources are provided in Sect. 3. The results in Sect. 4 are split between the gravity model estimates quantifying the trade effects of EU economic integration agreements, robustness checks, the evolution of EU EIA trade effects over time and the related counterfactual trade policy scenarios arising post Brexit. Section 5 concludes.

\section{Model specification and estimation strategy}

\subsection{The gravity model}

The gravity model specification of trade determinants has the following form: 


$$
T R A D E_{i j}^{t}=f\left(G D P_{i}^{t}, G D P_{j}^{t}, D I S T_{i j}, Z_{i j}, X_{i j}^{t}\right) \varepsilon_{i j}^{t}
$$

where $T R A D E_{i j}^{t}$ refers to bilateral trade between countries $i$ and $j$ over a given time period $t ; G D P_{i}^{t}$ and $G D P_{j}^{t}$ capture the economic size for both countries and $D I S T_{i j}$ is the geographic distance between their capital cities. Equation (1) also includes a vector of time invariant explanatory variables, $Z_{i j}$; a vector of time varying variables, $X_{i j}^{t}$; and the random error term, $\varepsilon_{i j}^{t}$

To capture the main determining factors of trade between the established EU15 countries and the rest of the world, the full model specification is as follows:

$$
\begin{aligned}
\ln \operatorname{IMPORTS}_{i j}^{t}= & \alpha_{0}+\beta_{1} \ln G D P_{i}^{t}+\beta_{2} \ln G D P_{j}^{t}+\beta_{3} \ln D I S T_{i j}+\beta_{4} D G D P P C_{i j}^{t} \\
& +\eta_{1} A D J_{i j}+\eta_{2} L O C K_{i j}+\eta_{3} C O L_{i j}+\eta_{4} L A N G_{i j} \\
& +\lambda_{1} \ln I N F R A S_{i j}^{t}+\lambda_{2} E I A_{i j}^{t}+\delta^{t}+\gamma_{i}+\omega_{j}+\varepsilon_{i j}^{t}
\end{aligned}
$$

where the natural logarithm $(\ln )$ of IMPORTS ${ }_{i j}^{t}$ are bilateral imports into the 15 established member countries of the EU (countries $i$ ) from the rest of the world (countries $j$ ) over the time period $t, 1960-2022$; and GDP per capita is stated in relative terms as the absolute difference in GDP per capita income levels, $D G D P P C_{i j}^{t}=\left|\ln G D P P C_{i}^{t}-\ln G D P P C_{j}^{t}\right|, \quad$ as a measure of relative factor endowments.

In its basic form, the standard gravity equation posits that bilateral trade increases with national income and declines with the distance between them. Anderson (1979) was the first to provide theoretical underpinnings for the gravity model using the properties of the expenditure equation of tradable goods whereby the origin country's GDP is a proxy for the production of traded goods and the destination country's GDP is a proxy for expenditure on traded goods. The derived gravity model also captured transport costs, hence GDP and distance, $D I S T_{i j}$, should be positively and negatively signed respectively.

In the augmented version of the gravity model, Bergstrand (1989) identifies separate roles for GDP and GDP per capita by amalgamating the factor proportions theory (primarily a supply oriented theory), and the demand based theory of similarity of demand characteristics within a Heckscher-Ohlin-Chamberlain-Linder framework. As an indirect way of testing the Linder (1961) hypothesis, Gruber and Vernon (1970) merge the separate roles of income per capita into the per capita income differential, $D G D P P C_{i j}^{t}$. A negative coefficient, suggesting trade is positively related to consumers with similar per capita incomes and therefore having similar consumption patterns, indicates support for the Linder hypothesis. In contrast, a positive coefficient suggests trade is driven more by differing per capita incomes consistent with the Heckscher-Ohlin model (Heckscher 1919; Ohlin 1933) of relative factor abundance.

The vector of time invariant bilateral factors, $Z_{i j}$, includes four binary coded dummy variables denoting adjacent borders, $A D J_{i j}$, and landlocked countries, $L O C K_{i j}$, as indicators for geographic proximity; historical colonial linkages, $C O L_{i j}$, as an indicator for institutional proximity, and a common ethnic language, $L A N G_{i j}$, 
as an indicator for cultural proximity. While commonalities between countries should boost trade, landlocked countries tend to be disadvantaged in trade terms because the overland costs of transporting goods are generally higher than shipping costs.

The vector of time varying explanatory variables, $X_{i j}^{t}$, is represented by the log of infrastructure, INFRA $S_{i j}^{t}$, and EU economic integration agreements, $E I A_{i j}^{t}$. The inclusion of infrastructure in a model of trade stems from Bougheas et al. (1999), who suggested that the level of infrastructure can affect trade via its influence on transport costs. They argue that transport costs are not only a function of distance, but also depend on the availability of public infrastructure such as roads, ports and telecommunication networks. Therefore, they augment the gravity model with direct measures of transport infrastructure, including the length of the motorway network. As trade depends inversely on transport costs and transport costs depend inversely on infrastructure, a positive relationship between the level of infrastructure and the volume of trade is predicted. Along these lines, Francois and Manchin (2013) assess the trade effect of both physical (air transport and roads) and communications infrastructure while Carrère (2006) quantifies the trade effect of infrastructure by constructing an index based on four variables (road density, roads paved, railways and telephone lines). Accordingly, Eq. (2) includes two measures of physical infrastructure, namely the $\log$ of the summed value of air freight, $\ln A I R_{i j}^{t}$, and similarly for rail lines, $\ln R A I L_{i j}^{t}$. While the former is important in transporting high value, small volume products such as pharmaceuticals and technology overseas, the latter-critical to the Industrial Revolution and the development of export economies-remains an important mode of transporting bulk and manufactured goods overland.

To capture the potential beneficial trade effects of EU economic integration agreements, $E I A_{i j}^{t}$, three binary coded dummies are constructed. ${ }^{6}$ First, a dummy variable denoting EU membership between 28 countries, $E U_{i}^{t}-E U_{j}^{t}$, is used to capture European intraregional integration. The expected positive trade effect of EU membership stems mainly from the deposed trade and nontrade barriers initiated under the programme to complete the single market. Indeed, the Internal Market programme brought about the mutual reduction and removal of several trade obstacles including substantial progress towards dismantling technical barriers to trade; the liberalisation of public procurement; and the development of simplified internal customs and fiscal controls (European Commission 1996).

Second, a dummy denoting membership of various trade related agreements including customs unions, free trade agreements, association agreements and stabilisation agreements between the EU and 38 countries, $E U_{i}^{t}-F T A_{j}^{t}$, are associated with the main aims of reducing or removing customs tariffs in bilateral trade.

Last, a dummy denoting membership of a full or interim economic partnership agreement, $E U_{i}^{t}-E P A_{j}^{t}$, is constructed between the EU and 28 African, Caribbean and Pacific (ACP) countries. In essence, the EPAs are trade and development

\footnotetext{
${ }^{6}$ In a similar vein, Vicard (2009) separately estimates the trade effects of RTAs according to four broad categories: preferential arrangements, free trade agreements, customs unions and common markets.
} 
partnerships with the main aims of providing duty free and quota free (DFQF) access to the EU market; fostering trade related cooperation; and promoting sustainable development through investment. These reciprocal regional EPAs are compatible with World Trade Organisation (WTO) rules and replace the unilateral preferences previously granted by the EU to many ACP countries under the Sugar Protocol. ${ }^{7}$ A summary of the EU trade related agreements is provided in the Appendix (Table 6).

\subsection{Estimation strategy}

Since its inception in the 1960s, the gravity model of trade has been traditionally estimated as a cross sectional regression (or for a series of cross sections when the evolution of trade is of interest) and, more recently, using panel estimators.

\subsubsection{Omitted variables}

Many of the empirical findings, however, are likely to suffer from endogeneity bias arising from the omission of trade cost variables that can differ depending on location. Three main approaches have been adopted in the literature. First, cross country variation in trade costs have been proxied by international differences in aggregate price indexes, for example, an exchange rate index, an export unit value index or the GDP deflator (Bergstrand 1989). This approach, however, entails a degree of arbitrary selection of price indexes without necessarily eliminating the omitted variable bias problem.

Second, to account for all those factors that impede bilateral trade, Anderson and van Wincoop (2003) compute multilateral price terms capturing bilateral trade costs relative to all other trading partner countries. Modifying model (1) to allow for multilateral trade resisting variables, the gravity model can be expressed as follows:

$$
\begin{aligned}
\ln I M P O R T S_{i j}^{t}= & \alpha_{0}+\beta_{1} \ln G D P_{i}^{t}+\beta_{2} \ln G D P_{j}^{t}+\beta_{3} \ln D I S T_{i j} \\
& +\eta_{1} Z_{i j}+\lambda_{1} X_{i j}^{t}-\ln P_{i}^{1-\sigma}-\ln P_{j}^{1-\sigma}+e_{i j}^{t}
\end{aligned}
$$

subject to $N$ equilibrium conditions

$$
P_{j}^{1-\sigma}=\sum_{i} P_{i}^{\sigma-1} \exp \left(\beta_{1} \ln G D P_{i}^{t}+\beta_{2} \ln G D P_{j}^{t}+\beta_{3} \ln D I S T_{i j}+\eta_{1} Z_{i j}+\lambda_{1} X_{i j}^{t}\right)
$$

\footnotetext{
7 The origin of trade preferences for the ACP countries goes back to the Treaty of Rome with a commitment to the prosperity of European (mostly French) colonies. After gaining independence, preferential treatment offered by six European countries to 19 (mostly African) former colonies was enshrined in the Yaoundé Conventions signed in 1963 and 1969 (Persson 2008). With the accession of the UK into the European Community (EC) in 1973, the preferences of British former colonies were accommodated by replacing Yaoundé with the Lomé Convention and expanding European-African cooperation to the Caribbean and Pacific countries (see, for example, Stack et al. 2018 on the trade effects of ACP preferential treatment).
} 
where $P_{i}^{1-\sigma}$ and $P_{j}^{1-\sigma}$ are the multilateral resistance terms for both countries, which replace the aggregate price indexes; and $\sigma$ is the elasticity of substitution between all goods.

Last, drawing on the gravity model specification by Mátyás (1997), Feenstra (2002) advocates the use of country fixed effects in preference to calculating complex price terms. As trade costs are often not directly observable or are difficult to measure, this approach has the advantage of generating unbiased coefficient estimates in the presence of measurement problems. Model (1) can thus be restated as:

$$
\ln I M P O R T S_{i j}^{t}=\alpha_{0}+\beta_{1} \ln G D P_{i}^{t}+\beta_{2} \ln G D P_{j}^{t}+\beta_{3} \ln D I S T_{i j}+\eta_{1} Z_{i j}+\lambda_{1} X_{i j}^{t}+\gamma_{i}+\omega_{j}+\mu_{i j}^{t}
$$

where the price terms are now represented by fixed effects for both countries, $\gamma_{i}$ and $\omega_{j}$, respectively. In essence, the inclusion of country fixed effects helps control for unobserved heterogeneity across countries.

With the additional dimensions of panel datasets, solving the omitted variable bias problem has emerged in the form of how to control correctly for heterogeneity across countries (Baltagi et al. 2003; Cheng and Wall 2005; Baldwin and Taglioni 2006; Stack 2009). Many studies have included bilateral fixed effects to control for unobserved time invariant heterogeneity (see, for example, Baier and Bergstrand 2007; Bergstrand et al. 2015). These studies have additionally included country time fixed effects to account for time varying exporter and importer multilateral heterogeneity. Indeed, the generalised gravity model for a panel (with both cross sectional and time dimensions) should include (time invariant) bilateral dummies, $\gamma \omega_{i j}$, to capture the omission of trade determinants across country pairs and time varying country dummies, $\gamma \delta_{i}^{t}$ and $\omega \delta_{j}^{t}$, to capture the variation of multilateral resistance over time (Baldwin and Taglioni 2006), where time specific effects, $\delta^{t}$, are interacted with the country fixed effects.

The generalised gravity model, however, is problematic in so far as greater data availability and larger panel datasets can incur an excessive number of fixed effects. Moreover, the time invariant variables, $Z_{i j}$, are subsumed into the country pair dummies and hence cannot be estimated directly. Similarly, the effects of GDP are largely captured by the time varying country dummies. Indeed, the issue of dimensionality can compromise the analysis of any variable of interest if it shares the same dimension as the fixed effects. Taken together, the inclusion of country pair dummies and time varying country dummies imply the core gravity variables of GDP and distance can no longer be estimated directly.

\subsubsection{Simultaneity}

While the inclusion of fixed effects helps control for one source of endogeneity (i.e. unobserved heterogeneity), it says little about endogeneity arising from a different 
source (i.e. simultaneity). ${ }^{8}$ Endogeneity bias can also arise from the simultaneous determination of the dependent variable and one or more of the explanatory variables. Baier and Bergstrand (2004) have previously highlighted the possibility of dual causality between RTAs and trade. In other words, the causality between RTAs and trade need not necessarily be unidirectional; the formation of RTAs can stem from or lead to higher trade flows.

To control for possible endogeneity arising from reverse causality, the model can be estimated using two stage least squares (2SLS) whereby one or more instrumental variables (IVs) are needed to replace RTAs, the potentially endogenous variable. There is no consensus, however, on what constitutes good instruments for RTAs in a trade equation. Magee (2003), for example, includes a joint democracy dummy variable and several economic variables as instruments for PTAs in a 2SLS panel regression of trade. For a large cross section of countries, Egger et al. (2011) generate IV estimates using historical and political dummy variables as instruments, namely, former colonies, former common colonisers and countries that were formerly part of the same country.

As instruments for the EU trade related agreements, the value of unity for the respective EIA dummies is replaced with geographic variables, namely joint land area and joint continents. These geographic variables are candidate instruments for EIAs on the grounds that the process of EU enlargement and the formation of trade related agreements with other countries have expanded free trade coverage to large tracts of land area, including much of the European continent and beyond. Indeed, the EU has negotiated trade deals with countries from all continents of the world (Africa, the Americas, Asia, Europe and the Pacific).

In the context of this study, good instruments should satisfy two requirements: first, they should have no direct effect on trade, and second, they should have a direct effect on the formation of RTAs. As the existing literature does not usually include these types of geographic variables in the gravity model, it is not unreasonable to treat them as excludable from the trade equation. On the other hand, a strong association between geography and PTAs have previously been noted. For example, the WTO (2011) point out that only half of all RTAs are from the same region. Lake and Yildiz (2016) also highlight the importance of geographic characteristics in the choice of PTAs. Indeed, simple correlations suggest these geographic variables may well play an important role in explaining RTAs. ${ }^{9}$

By combining instrumental variables estimation with panel data methods, the parameters can be estimated consistently in the presence of unobserved (fixed) effects and endogeneity of the time varying explanatory variables (Wooldridge 2014). In short, estimating the gravity model specification (2) as a 2SLS regression with time and country fixed effects draws on a combination of theoretical developments

\footnotetext{
${ }^{8}$ An explanatory variable is endogenous if it is correlated with the equation's error term. According to Wooldridge (2002), endogeneity usually arises in one of three ways: omitted variables, simultaneity and measurement error.

9 The (simple) correlation between the instruments and the EU EIAs (merged into a single dummy) is relatively high $(0.54$ and 0.93$)$ compared with the correlation between the instruments and imports respectively $(0.21$ and 0.32$)$.
} 
(Anderson 1979; Bergstrand 1989; Bougheas et al. 1999; Anderson and van Wincoop 2003) and helps control for two sources of endogeneity bias, namely unobserved heterogeneity (Mátyás 1997; Feenstra 2002) and simultaneity (Baier and Bergstrand 2004). In addition to controlling for two sources of endogeneity, the relative simplicity and ease of implementation in software are among the main benefits of this approach compared with other methods adopted in the literature. ${ }^{10}$

\section{Data}

The panel data set consists of bilateral imports ${ }^{11}$ into the 15 established member countries of the $\mathrm{EU}^{12}$ from the rest of the world ${ }^{13}$ over the $1960-2022$ period. The sample period includes actual data (1960-2016) and forecast data (2017-2022), the latter able to account for the trade effects of economic integration associated with recently formed trade agreements as well as economic disintegration associated with the planned exit of the UK from the EU.

The data definitions and sources are as follows. Bilateral imports (cost, insurance, freight) over the 1960-2016 period, in US dollars, are sourced from the Direction of Trade Statistics (DOTS), International Monetary Fund (IMF 2017). For the years 2017-2022, data projections for trade growth are taken from the World Economic Outlook Database (WEO), IMF (2018a, b). Note that bilateral imports are calculated on the assumption that export growth projections for the partner countries apply equally across all the EU15 trading partners. ${ }^{14}$

Data on GDP and GDP per capita, in current US dollars, for the years 1980-2022 are from the WEO, ${ }^{15}$ supplemented with pre 1980 data from the World Development Indicators (WDI), World Bank (2017).

\footnotetext{
${ }^{10}$ For example, in splitting the sample into a control period and a treatment period, the use of a synthetic matching algorithm is required for the synthetic control method (Douch et al. 2017). Anderson et al.'s (2015) three step estimation procedure to obtaining estimates of the general equilibrium effects of trade policy is also much more involved than the approach of this study.

11 Bilateral import data are used in preference to bilateral export data because of greater susceptibility to trade policy changes. Import data also tend to be more reliable because governments have an incentive to track information on imports as it constitutes a tax base (Francois and Manchin 2013).

12 Austria, Belgium, Luxembourg, Denmark, Finland, France, Germany, Greece, Ireland, Italy, the Netherlands, Portugal, Spain, Sweden and the UK.

13 The country coverage is based on the 193 countries included in the IMF's WEO database.

14 Take, for example, Poland. For the years 2017-2022, the WEO export growth forecast values (in percentage terms) are 7.5, 7.1, 6.6, 6.1, 5.7 and 5.3 respectively. Therefore, assuming trade growth rises equally across all the EU15 countries, the forecast bilateral import values for 2017 will be $7.5 \%$ higher than actual bilateral import values for 2016, which in turn, for 2018 will be $7.1 \%$ higher than the bilateral import values for 2017 and so forth.

15 The IMF's WEO data projections of selected macroeconomic data evolve according to economic developments and policies in individual countries, developments in international financial markets as well as the global economic system (IMF 2018b). Therefore, the forecast data taken from the WEO's April 2018 edition will have incorporated downward revisions in lieu of the June 2016 referendum (and the 2014-2015 global slowdown), but will not have included the effects of more recent events such as the US-China trade war and the global Covid-19 pandemic.
} 
Also sourced from the WDI are the infrastructure related variables, namely the freight of air transport, in million tonnes per kilometre, and rail lines, total routes per kilometre, with forecast data generated using 2000-2016 period averages.

The geographic distance between two capital cities, in kilometres, is obtained from CEPII (2018) and similarly for the dummy variables denoting an adjacent border, landlocked countries, a common colonial history and a common ethnic language.

The EIA dummies are constructed based on information from the European Commission (2018) and the World Trade Organisation (2018). In essence, the binary coded EIA dummies switch from zero to one when a given trade deal comes into force.

\section{Empirical results}

\subsection{Gravity model results}

Table 1 presents the results for the gravity model of import determinants between the EU15 countries and the rest of the world over the period 1980 to $2022 .{ }^{16}$ Column (1) shows the results using least squares estimation with time and country fixed effects, the latter accounting for (unobservable) variation of characteristics across countries. Column (2) shows the corresponding results estimated using 2 SLS. ${ }^{17}$ In columns (1) and (2), all EU trade related agreements are merged into a single EIA indicator capturing trade relations with 94 countries while in columns (3) and (4), the EIA indicator is split into three separate dummies according to EU membership between 28 countries; various trade related agreements including customs unions, free trade agreements, association agreements and stabilisation agreements with 38 countries; and membership of a full or interim EPA with 28 ACP countries.

Note that the goodness of fit $\left(R^{2}\right)$ is satisfactory across the estimators, with the independent variables explaining four fifths of the variance of the dependent variable. The null hypothesis that the EIA dummies are exogenous is rejected by both the robust Chi squared $\left(\chi^{2}\right)$ score test and the robust regression $F$ test (Wooldridge 1995), confirming the endogeneity of EIAs and thereby indicating the suitability of

\footnotetext{
16 Note that the number of observations is reduced by the inclusion of the infrastructure variables in the model (data for air freight and rail lines are available from 1970 and 1980 onwards respectively).

17 Anderson et al. (2015) suggest the country fixed effects should be time varying for panel data, but this would entail a large number of dummies while collinearity with the instruments would mean that the 2 SLS equation would no longer be identified. Therefore, time specific effects that control for common shocks - such as the global financial crisis and the more recent 2014-2015 general slowdown-are included in the model instead.
} 
Table 1 EU import determinants

\begin{tabular}{|c|c|c|c|c|}
\hline \multirow[t]{2}{*}{ Regressors } & \multicolumn{2}{|c|}{ EU EIAs aggregated } & \multicolumn{2}{|c|}{ EU EIAs disaggregated } \\
\hline & $(1)^{\mathrm{a}}$ & $(2)^{b}$ & $(3)^{a}$ & $(4)^{b}$ \\
\hline Importer GDP (ln) & $\begin{array}{l}0.37 * * \\
(7.61)\end{array}$ & $\begin{array}{l}0.36 * * \\
(7.53)\end{array}$ & $\begin{array}{l}0.35 * * \\
(7.32)\end{array}$ & $\begin{array}{l}0.36 * * \\
(7.36)\end{array}$ \\
\hline Partner GDP (ln) & $\begin{array}{l}0.25 * * \\
(8.48)\end{array}$ & $\begin{array}{l}0.25 * * \\
(8.64)\end{array}$ & $\begin{array}{l}0.26 * * \\
(8.87)\end{array}$ & $\begin{array}{l}0.26 * * \\
(8.67)\end{array}$ \\
\hline GDP per capital difference (ln) & $\begin{array}{l}-0.36^{* *} \\
(-18.64)\end{array}$ & $\begin{array}{l}-0.36^{* *} \\
(-18.40)\end{array}$ & $\begin{array}{l}-0.33 * * \\
(-16.88)\end{array}$ & $\begin{array}{l}-0.34 * * \\
(-16.93)\end{array}$ \\
\hline Distance $(\ln )$ & $\begin{array}{l}-1.21^{* *} \\
(-59.49)\end{array}$ & $\begin{array}{l}-1.21 * * \\
(-59.52)\end{array}$ & $\begin{array}{l}-1.22^{* *} \\
(-59.64)\end{array}$ & $\begin{array}{l}-1.22 * * \\
(-59.66)\end{array}$ \\
\hline Adjacency & $\begin{array}{l}-0.12 * * \\
(-3.48)\end{array}$ & $\begin{array}{l}-0.12 * * \\
(-3.48)\end{array}$ & $\begin{array}{l}-0.12^{* * *} \\
(-3.49)\end{array}$ & $\begin{array}{l}-0.12 * * \\
(-3.46)\end{array}$ \\
\hline Landlocked & $\begin{array}{l}-0.29 * * \\
(-2.88)\end{array}$ & $\begin{array}{l}-0.29 * * \\
(-2.90)\end{array}$ & $\begin{array}{l}-0.29 * * \\
(-2.94)\end{array}$ & $\begin{array}{l}-0.29 * * \\
(-2.91)\end{array}$ \\
\hline Colony & $\begin{array}{l}0.79 * * \\
(25.99)\end{array}$ & $\begin{array}{l}0.79 * * \\
(26.03)\end{array}$ & $\begin{array}{l}0.78 * * \\
(25.85)\end{array}$ & $\begin{array}{l}0.78 * * \\
(25.94)\end{array}$ \\
\hline Ethnic language & $\begin{array}{l}0.33 * * \\
(10.65)\end{array}$ & $\begin{array}{l}0.33 * * \\
(10.67)\end{array}$ & $\begin{array}{l}0.33 * * \\
(10.62)\end{array}$ & $\begin{array}{l}0.33 * * \\
(10.62)\end{array}$ \\
\hline Air freight (ln) & $\begin{array}{l}0.17 * * \\
(11.84)\end{array}$ & $\begin{array}{l}0.16^{* * *} \\
(11.79)\end{array}$ & $\begin{array}{l}0.16 * * \\
(11.79)\end{array}$ & $\begin{array}{l}0.16^{* *} \\
(11.73)\end{array}$ \\
\hline Rail lines (ln) & $\begin{array}{l}0.30 * * \\
(9.94)\end{array}$ & $\begin{array}{l}0.30 * * \\
(10.06)\end{array}$ & $\begin{array}{l}0.29 * * \\
(9.84)\end{array}$ & $\begin{array}{l}0.29 * * \\
(9.88)\end{array}$ \\
\hline EU-EIA & $\begin{array}{l}0.30 * * \\
(13.41)\end{array}$ & $\begin{array}{l}0.38 * * \\
(18.16)\end{array}$ & - & - \\
\hline EU-EU & - & - & $\begin{array}{l}0.40 * * \\
(17.86)\end{array}$ & $\begin{array}{l}0.39 * * \\
(15.29)\end{array}$ \\
\hline EU-FTA & - & - & $\begin{array}{l}0.29 * * \\
(9.11)\end{array}$ & $\begin{array}{l}0.41 * * \\
(9.88)\end{array}$ \\
\hline EU-EPA & - & - & $\begin{array}{l}-0.23 * * \\
(-2.39)\end{array}$ & $\begin{array}{l}-0.26^{* *} \\
(-2.81)\end{array}$ \\
\hline No. of obs & 38326 & 38326 & 38326 & 38326 \\
\hline$R_{2}$ & 0.83 & 0.83 & 0.84 & 0.84 \\
\hline Partial $R_{2}^{\mathrm{c}}$ & - & 0.86 & - & 0.73 \\
\hline Robust $\chi^{2}$ score test ${ }^{\mathrm{d}}$ & - & $61.75^{* * *}$ & - & $37.94 * *$ \\
\hline Robust regression $F$-test ${ }^{\mathrm{d}}$ & - & $60.40 * *$ & - & $11.57 * *$ \\
\hline$\chi^{2}$ score test ${ }^{\mathrm{e}}$ & - & $21.96^{* *}$ & - & $26.70 * *$ \\
\hline
\end{tabular}

The $t$-statistics ( $z$-statistics for 2SLS) in parentheses are heteroscedasticity robust

**denotes significance at the $5 \%$ level; *denotes significance at the $10 \%$ level

${ }^{a}$ Least squares estimation with time and country fixed effects

${ }^{b}$ 2SLS estimation with time and country fixed effects

${ }^{\mathrm{c}}$ The first stage summary statistics in column (2) refer to the partial $\mathrm{R}^{2}$ for the model with one endogenous. EIA dummy and in column (4) refer to Shea's (1997) partial $\mathrm{R}^{2}$ statistics (0.73, 0.47 and 0.76) associated with multiple endogenous EIA dummies

${ }^{\mathrm{d}}$ Tests of the null hypothesis that the EIA dummies are exogenous (Wooldridge 1995)

${ }^{\text {e}}$ Test of overidentifying restrictions (Wooldridge 1995) 
instrumental variables regression. The relatively high values for the first stage partial $\mathrm{R}^{2}$ statistics suggest high explanatory power of the instruments. In other words, the instruments are strongly correlated with the endogenous EIA dummies-after netting out the effects of the exogenous variables. The test of overidentifying restrictions (Wooldridge 1995), however, rejects the null hypothesis of valid instruments. More specifically, the significant Chi squared $\left(\chi^{2}\right)$ score test statistic suggests that at least one of the instruments may be correlated with the structural error term. In general, finding good instruments that satisfy the twin requirements that the instruments be correlated with the endogenous variable, but uncorrelated with the dependent variable is challenging.

The results shown in Table 1 suggest the model coefficient signs are broadly in line with theoretical priors. Specifically, the positive and significant coefficients for GDP suggest larger countries tend to trade more while the per capita income difference coefficients are aligned with the Linder hypothesis in so far as factor endowments are sufficiently similar between the two groups of countries.

Higher transport costs, however, reduce the volume of trade, as indicated by the distance coefficients. The trade impeding effects associated with the geographic characteristics of landlocked countries and adjacent land borders are also apparent. The lack of access to the sea for landlocked countries tends to raise transport costs. Similarly, national boundaries can increase trade related costs, contractual obligations and time in transit by imposing import tariffs, declarations in terms of the origin of goods as well as border checks and delays.

In contrast, a shared colonial history and a common language significantly increase bilateral trade. In other words, a mutual linguistic or cultural heritageoften arising from past colonial linkages-contribute to current trade patterns because familiarity with foreign customs and norms help lower transaction costs and payment frictions associated with trade. ${ }^{18}$ Both measures of physical infrastructure (air freight and rail lines) also enhance trade.

Of particular interest are the distinct trade effects of the EIA dummies. Overall, the single EIA dummy coefficient confirms the trade enhancing effect of economic integration (column 2). ${ }^{19}$ Splitting the EIA indicator according to the type of arrangement, however, yields nonuniform trade effects: positive, significant and of similar magnitude for EU membership and the FTAs, but negative and significant (and smaller in magnitude) for the regional EPAs.

The recent timing in the formation (and ongoing negotiation) help explain why the regional EPAs do not yet have a positive effect on bilateral imports. Other contributing factors may include the tendency towards exporting a narrow range of commodity types to the EU, for example, sugar, coffee, fish, tobacco, copper and crude oil from the Eastern and Southern African (ESA) countries as well as various country characteristics such as the mostly small island countries that make up the

\footnotetext{
${ }^{18}$ Language is defined as a country's ethnic language spoken by at least 9 per cent of a country's population. The results are also robust to the use of the official or national language.

19 In percentage terms, the effect of the EIA dummy on imports is 46 per cent, calculated as: $[\exp (0.38)-1 \times 100]$.
} 
CARIFORUM EPA or the many African countries with greater scope for prospective (rather than realised) trade and development potential.

Note that controlling for simultaneity brings about a relatively small increase in the coefficient magnitude of the overall EU- EIA dummy (column 2) and the EU-FTA dummy (column 4) when compared with controlling for heterogeneity alone, otherwise the model coefficients are similar. Baier and Bergstrand (2007) have previously highlighted the possibility of simultaneity bias arising from the EIA coefficient estimates, although they suggest that such bias is more important for a cross sectional gravity equation rather than for a panel.

\subsection{Robustness checks}

Several robustness tests are undertaken to check the sensitivity of the results. First, to test whether the results are sensitive to the measure of overland transport infrastructure, the summed value of rail lines is replaced with the corresponding value of road density, $\ln R O A D_{i j}^{t}$, (i.e. the length of a country's road network per 100 square kilometres of land area), sourced from the Food and Agriculture Organization (FAO 2018). Second, to check the sensitivity of the results across different subgroups of countries, the model is reestimated for two subsamples, the first comprising intraEU trade between the 28 EU member countries and the second involving the 94 countries for which the EU has a trade related agreement. Third, the model is reestimated using an alternative estimator, namely the 2 way (bilateral) fixed effects model, which accounts for heterogeneity in a cross sectional dimension. To control for possible endogeneity of GDP, the 2 SLS regression is also rerun with the lag of GDP as an instrument.

The results for the robustness checks are shown in Table 2. For ease of comparison, the 2SLS benchmark specification is shown in column (1). Column (2) shows the trade effect of road density. Columns (3) and (4) show the subsample results. In column (5), the 2SLS estimates additionally control for GDP endogeneity and in column (6), the results are shown when controlling for cross sectional heterogeneity.

Across the range of sensitivity checks, the coefficient estimates for the EIA dummies are broadly robust, although the EU-EPA dummy coefficient loses significance when the model includes road density (column 2) or is estimated using the standard fixed effects estimator (column 6). There is also some variation in the magnitude and significance of the remaining model coefficients, especially for the EU subsample of countries (column 3). In particular, the change in the coefficient sign for adjacency highlights the beneficial trade effects of open borders within the EU countries in contrast to the larger sample of countries. Similarly, landlocked countries are no longer geographically disadvantaged ${ }^{20}$ — and even become significantly advantaged when connected by a good network of roads (column 2). Taken together, the importance of roads (column 2) and the relegation of rail lines to insignificance for the EU

\footnotetext{
${ }^{20}$ Located in the heart of Europe are five landlocked countries: Austria, the Czech Republic, Hungary, Luxembourg and Slovakia.
} 
Table 2 Robustness Checks

\begin{tabular}{|c|c|c|c|c|c|c|}
\hline Regressors & $\begin{array}{l}\text { (1) } \\
\text { Benchmark }\end{array}$ & $\begin{array}{l}(2) \\
\text { Road density }\end{array}$ & $\begin{array}{l}(3) \\
E U-28\end{array}$ & $\begin{array}{l}(4) \\
E U-94\end{array}$ & $\begin{array}{l}\text { (5) } \\
\text { GDP endogeneity }\end{array}$ & $\begin{array}{l}\text { (6) } \\
\text { 2-way FE }\end{array}$ \\
\hline Importer GDP (ln) & $\begin{array}{l}0.36 * * \\
(7.36)\end{array}$ & $\begin{array}{l}0.41 * * \\
(4.51)\end{array}$ & $\begin{array}{l}0.37 * * \\
(8.69)\end{array}$ & $\begin{array}{l}0.50 * * \\
(9.85)\end{array}$ & $\begin{array}{l}0.28 * * \\
(5.44)\end{array}$ & $\begin{array}{l}0.70 * * \\
(6.53)\end{array}$ \\
\hline Partner GDP (ln) & $\begin{array}{l}0.26 * * \\
(8.67)\end{array}$ & $\begin{array}{l}0.33 * * \\
(5.76)\end{array}$ & $\begin{array}{l}0.67 * * \\
(20.60)\end{array}$ & $\begin{array}{l}0.49 * * \\
(14.60)\end{array}$ & $\begin{array}{l}0.38 * * \\
(10.21)\end{array}$ & $\begin{array}{l}0.24 * * \\
(2.78)\end{array}$ \\
\hline $\begin{array}{l}\text { GDP per capital dif- } \\
\text { ference }(\ln )\end{array}$ & $\begin{array}{l}-0.34 * * \\
(-16.93)\end{array}$ & $\begin{array}{l}-0.20 * * \\
(-5.47)\end{array}$ & $\begin{array}{l}0.20 * * \\
(10.24)\end{array}$ & $\begin{array}{l}-0.08 * * \\
(-3.89)\end{array}$ & $\begin{array}{l}-0.26 * * \\
(-11.24)\end{array}$ & $\begin{array}{l}-0.38 * * \\
(-5.14)\end{array}$ \\
\hline Distance (ln) & $\begin{array}{l}-1.22 * * \\
(-59.66)\end{array}$ & $\begin{array}{l}-1.20 * * \\
(-39.28)\end{array}$ & $\begin{array}{l}-1.08 * * \\
(-70.86)\end{array}$ & $\begin{array}{l}-1.18 * * \\
(-63.46)\end{array}$ & $\begin{array}{l}-1.23 * * \\
(-59.45)\end{array}$ & - \\
\hline Adjacency & $\begin{array}{l}-0.12 * * \\
(-3.46)\end{array}$ & $\begin{array}{l}-0.25 * * \\
(-4.52)\end{array}$ & $\begin{array}{l}0.33 * * \\
(12.82)\end{array}$ & $\begin{array}{l}-0.06^{*} \\
(-1.88)\end{array}$ & $\begin{array}{l}-0.12 * * \\
(-3.46)\end{array}$ & - \\
\hline Landlocked & $\begin{array}{l}-0.29 * * \\
(-2.91)\end{array}$ & $\begin{array}{l}0.59 * * \\
(5.83)\end{array}$ & $\begin{array}{l}0.01 \\
(0.15)\end{array}$ & $\begin{array}{l}0.06 \\
(0.61)\end{array}$ & $\begin{array}{l}-0.30 * * \\
(-3.01)\end{array}$ & - \\
\hline Colony & $\begin{array}{l}0.78 * * \\
(25.94)\end{array}$ & $\begin{array}{l}1.02 * * \\
(22.84)\end{array}$ & $\begin{array}{l}0.44 * * \\
(10.65)\end{array}$ & $\begin{array}{l}0.90 * * \\
(23.88)\end{array}$ & $\begin{array}{l}0.78 * * \\
(25.79)\end{array}$ & - \\
\hline Ethnic language & $\begin{array}{l}0.33 * * \\
(10.62)\end{array}$ & $\begin{array}{l}0.50 * * \\
(11.33)\end{array}$ & $\begin{array}{l}-0.17 * * \\
(-4.60)\end{array}$ & $\begin{array}{l}0.26 * * \\
(7.51)\end{array}$ & $\begin{array}{l}0.33 * * \\
(10.74)\end{array}$ & - \\
\hline Air freight $(\ln )$ & $\begin{array}{l}0.16^{* *} \\
(11.73)\end{array}$ & $\begin{array}{l}0.23 * * \\
(12.39)\end{array}$ & $\begin{array}{l}0.15^{* *} \\
(11.75)\end{array}$ & $\begin{array}{l}0.19 * * \\
(12.99)\end{array}$ & $\begin{array}{l}0.16^{* *} \\
(11.28)\end{array}$ & $\begin{array}{l}0.08 * \\
(1.79)\end{array}$ \\
\hline Rail lines (ln) & $\begin{array}{l}0.29 * * \\
(9.88)\end{array}$ & - & $\begin{array}{l}0.03 \\
(1.18)\end{array}$ & $\begin{array}{l}0.24 * * \\
(6.94)\end{array}$ & $\begin{array}{l}0.29 * * \\
(9.84)\end{array}$ & $\begin{array}{l}0.21 \\
(1.42)\end{array}$ \\
\hline Road density (ln) & - & $\begin{array}{l}0.45 * * \\
(8.03)\end{array}$ & - & - & - & - \\
\hline EU-EU & $\begin{array}{l}0.39 * * \\
(15.29)\end{array}$ & $\begin{array}{l}0.14 * * \\
(2.91)\end{array}$ & $\begin{array}{l}0.35 * * \\
(15.98)\end{array}$ & $\begin{array}{l}0.33 * * \\
(13.64)\end{array}$ & $\begin{array}{l}0.40 * * \\
(15.62)\end{array}$ & $\begin{array}{l}0.48 * * \\
(10.68)\end{array}$ \\
\hline EU-FTA & $\begin{array}{l}0.41 * * \\
(9.88)\end{array}$ & $\begin{array}{l}0.25 * * \\
(3.48)\end{array}$ & - & $\begin{array}{l}0.09 * * \\
(2.03)\end{array}$ & $\begin{array}{l}0.41 * * \\
(9.94)\end{array}$ & $\begin{array}{l}0.30 * * \\
(5.15)\end{array}$ \\
\hline EU-EPA & $\begin{array}{l}-0.26^{* *} \\
(-2.81)\end{array}$ & $\begin{array}{l}-0.80 \\
(-1.33)\end{array}$ & - & $\begin{array}{l}-0.68 * * \\
(-7.25)\end{array}$ & $\begin{array}{l}-0.25 * * \\
(-2.78)\end{array}$ & $\begin{array}{l}-0.21 \\
(-1.10)\end{array}$ \\
\hline No. of obs & 38326 & 22531 & 11193 & 21985 & 38174 & 38326 \\
\hline$R^{2}$ & 0.84 & 0.85 & 0.93 & 0.87 & 0.84 & 0.37 \\
\hline
\end{tabular}

2SLS estimation with time and country fixed effects

The $z$-statistics in parentheses are heteroscedasticity robust

**denotes significance at the $5 \%$ level; *denotes significance at the $10 \%$ level

subsample (column 3) is not surprising in so far as roads account for over $70 \%$ of all inland transport modes in the EU, quadrupling the share transported by rail (European Commission 2017). ${ }^{21}$ Ethnic language, however, becomes negative and significant, reflecting the diversity of cultures among this more narrowly defined group of countries.

\footnotetext{
21 The inclusion of road density in the model substantially reduces the number of observations (data are available for the years 1990-2011 only), hence rail lines is used as the preferred measure of a country's internal transport network in the main results.
} 
Table 3 Evolution of EIA effects

\begin{tabular}{|c|c|c|c|c|c|}
\hline Regressors & $\begin{array}{l}(1) \\
1960-2016\end{array}$ & $\begin{array}{l}(2) \\
1973-2016\end{array}$ & $\begin{array}{l}(3) \\
1989-2016\end{array}$ & $\begin{array}{l}\text { (4) } \\
2007-2016\end{array}$ & $\begin{array}{l}(5) \\
2017-2022\end{array}$ \\
\hline Importer GDP (ln) & $\begin{array}{l}0.61 * * \\
(15.94)\end{array}$ & $\begin{array}{l}0.39 * * \\
(8.35)\end{array}$ & $\begin{array}{l}0.10 \\
(1.28)\end{array}$ & $\begin{array}{l}0.75^{* *} * \\
(2.73)\end{array}$ & $\begin{array}{l}0.61 \\
(0.47)\end{array}$ \\
\hline Partner GDP (ln) & $\begin{array}{l}0.66^{* * *} \\
(28.04)\end{array}$ & $\begin{array}{l}0.60 * * \\
(20.12)\end{array}$ & $\begin{array}{l}0.40 * * \\
(8.91)\end{array}$ & $\begin{array}{l}-0.19 \\
(-1.22)\end{array}$ & $\begin{array}{l}0.12 \\
(0.31)\end{array}$ \\
\hline $\begin{array}{l}\text { GDP per capita } \\
\text { difference }(\ln )\end{array}$ & $\begin{array}{l}-0.24 * * \\
(-14.20)\end{array}$ & $\begin{array}{l}-0.14^{* *} \\
(-6.64)\end{array}$ & $\begin{array}{l}-0.26 * * \\
(-10.01)\end{array}$ & $\begin{array}{l}-0.46^{* *} \\
(-8.00)\end{array}$ & $\begin{array}{l}-0.61 * * \\
(-12.53)\end{array}$ \\
\hline Distance (ln) & $\begin{array}{l}-1.24 * * \\
(-61.07)\end{array}$ & $\begin{array}{l}-1.27 * * \\
(-58.74)\end{array}$ & $\begin{array}{l}-1.24 * * \\
(-50.40)\end{array}$ & $\begin{array}{l}-1.20 * * \\
(-26.16)\end{array}$ & $\begin{array}{l}-1.37 * * \\
(-29.89)\end{array}$ \\
\hline Adjacency & $\begin{array}{l}-0.35 * * \\
(-9.77)\end{array}$ & $\begin{array}{l}-0.28^{* *} \\
(-7.48)\end{array}$ & $\begin{array}{l}-0.19 * * \\
(-4.66)\end{array}$ & $\begin{array}{l}-0.15^{* *} \\
(-2.07)\end{array}$ & $\begin{array}{l}-0.12 \\
(-1.40)\end{array}$ \\
\hline Landlocked & $\begin{array}{l}0.10 \\
(1.56)\end{array}$ & $\begin{array}{l}0.17 * * \\
(2.20)\end{array}$ & $\begin{array}{l}0.20^{*} \\
(1.82)\end{array}$ & $\begin{array}{l}-0.14 \\
(-0.75)\end{array}$ & $\begin{array}{l}-0.85^{* *} \\
(-4.60)\end{array}$ \\
\hline Colony & $\begin{array}{l}1.11 * * \\
(43.00)\end{array}$ & $\begin{array}{l}0.97 * * \\
(33.45)\end{array}$ & $\begin{array}{l}0.78 * * \\
(21.08)\end{array}$ & $\begin{array}{l}0.83 * * \\
(11.06)\end{array}$ & $\begin{array}{l}0.78 * * \\
(11.17)\end{array}$ \\
\hline Ethnic language & $\begin{array}{l}0.56^{* * *} \\
(20.25)\end{array}$ & $\begin{array}{l}0.50 * * \\
(16.52)\end{array}$ & $\begin{array}{l}0.36^{* *} \\
(9.49)\end{array}$ & $\begin{array}{l}0.34 * * \\
(4.84)\end{array}$ & $\begin{array}{l}0.18 * * \\
(2.66)\end{array}$ \\
\hline Air freight (ln) & - & $\begin{array}{l}0.18 * * \\
(15.91)\end{array}$ & $\begin{array}{l}0.16^{* * *} \\
(9.07)\end{array}$ & $\begin{array}{l}0.04 \\
(1.32)\end{array}$ & $\begin{array}{l}0.15^{* * *} \\
(4.80)\end{array}$ \\
\hline Rail lines (ln) & - & - & $\begin{array}{l}0.28 * * \\
(8.09)\end{array}$ & $\begin{array}{l}0.54 * * \\
(8.59)\end{array}$ & $\begin{array}{l}0.26^{* * *} \\
(3.70)\end{array}$ \\
\hline EU-EU & $\begin{array}{l}0.60 * * \\
(24.77)\end{array}$ & $\begin{array}{l}0.35 * * \\
(12.84)\end{array}$ & $\begin{array}{l}0.12^{* * *} \\
(3.10)\end{array}$ & $\begin{array}{l}0.23 \\
(0.37)\end{array}$ & $\begin{array}{l}0.50^{* * *} \\
(4.41)\end{array}$ \\
\hline EU-FTA & $\begin{array}{l}0.73 * * \\
(20.77)\end{array}$ & $\begin{array}{l}0.53 * * \\
(12.62)\end{array}$ & $\begin{array}{l}0.31 * * \\
(4.66)\end{array}$ & $\begin{array}{l}-0.16 \\
(-0.56)\end{array}$ & $\begin{array}{l}-0.31 * \\
(-1.93)\end{array}$ \\
\hline EU-EPA & $\begin{array}{l}-0.21 * * \\
(-3.27)\end{array}$ & $\begin{array}{l}-0.09 \\
(-1.13)\end{array}$ & - & - & $\begin{array}{l}-2.00 * * \\
(-4.18)\end{array}$ \\
\hline No. of obs & 101449 & 71051 & 22740 & 7432 & 8814 \\
\hline$R^{2}$ & 0.79 & 0.80 & 0.85 & 0.85 & 0.85 \\
\hline
\end{tabular}

2SLS estimation with time and country fixed effects

The $z$-statistics in parentheses are heteroscedasticity robust

**denotes significance at the $5 \%$ level; *denotes significance at the $10 \%$ level

\subsection{Evolution of EIA effects}

It is also interesting to consider the evolution of the EIA effects on trade. In other words, to determine if there are any discernible differences in the EIA coefficients over time, the model is reestimated for five subperiods. The subperiod results are shown in Table 3. In columns (1) and (5), the full sample period is split between actual data (1960-2016) and forecast data (2017-2022) respectively; in columns (2) 
to (4), the actual data are split into consecutively shorter and more recent periods, capturing different eras of major global shocks.

While the first subperiod (1960-2016) includes the 1960s, a period of growth and tranquillity during the post World War II expansion, during the 1970s of the second subperiod (1973-2016) the world economy was propelled into two major oil price crises. During the third subperiod (1989-2016), the late 1980s ushered in an economic downturn affecting much of the western world. During the fourth and most recent subperiod (2007-2016), the global financial crisis and the ensuing debt crisis plunged the world economy into its worst recession since the 1930s. This phase also includes a general slowdown in 2014-2015 linked to China's decelerating growth and falling commodity prices. The June 2016 referendum to withdraw the UK from the EU also occurred during this time frame with potentially far reaching consequences into the future. Looking ahead, the final subperiod (2017-2022) based on forecast data is helpful towards analysing the trade effects of economic integration associated with recently formed trade agreements as well as economic disintegration associated with the planned exit of the UK from the EU.

The subperiod results suggest the positive coefficients of EU and FTA membership tend to diminish over time. In other words, earlier membership of EIAs came with greater trade benefits, helped by the signing of the 1986 Single European Act that created the Single Market, culminating in the 'four freedoms' relating to goods, services, people and money across EU borders. Indeed, by the fourth subperiod the beneficial effects of EIA membership have dwindled away into insignificance, likely reflecting the fallout of the global financial crisis, its aftermath and the debt crisis in Europe, all of which brought about sharply declining growth of GDP and lower demand for imports. The forecast subperiod, however, suggests a rebound in the trade effect of EU membership, probably linked to the growing importance of intra industry trade and the exchange of similar, but differentiated goods, as suggested by the rising magnitude of the GDP per capita difference coefficient. In contrast, the prospective trade effects of FTAs and the regional EPAs are subdued and even adversarial.

In terms of the remaining model variables, the subperiod results suggest that similarity of per capita incomes in accordance with the Linder hypothesis more recently supersedes GDP in explaining EU import patterns, while transport costs remain broadly stable, as suggested by the distance coefficient. The downside of land borders decreases into insignificance in contrast to landlocked countries, which face substantial constraints in the forecast subperiod. The gains from colonial linkages have weakened since the 1960 s, when many countries gained independence, consistent with the findings of Head et al. (2010). Similarly, the effects of cultural heritage have eroded over time. Finally, the coefficients for infrastructure are broadly stable, except for the fourth subperiod when belt tightening during the financial crisis favoured cheaper transport modes, including railways, over the speedier, but more costly mode of air transport. As the economy recovers from the financial crisis, the logistics industry looks set to return to the more normal mix of transport modes. 


\subsection{Counterfactual predictions}

The predicted values for alternative counterfactual trade policy scenarios are also generated. A typical counterfactual comparative static exercise using the gravity model involves hypothetically changing some bilateral friction (for example, the removal of a tariff) and calculating the effects on trade flows (Anderson et al. 2015). Following the burgeoning Brexit related literature, the counterfactual change in the dependent variable is estimated by hypothetically altering the values for the RTA indicator (Brakman et al. 2018; Oberhofer and Pfaffermayr 2018).

On this basis, the trade effects of three alternative counterfactual scenarios are estimated by changing the values for the single EIA indicator capturing bilateral trade relations. First, under the 'hard Brexit' scenario, the EIA indicator is set to zero for all UK EU bilateral trading pairs from 2019 onwards, indicating a change in trade relations with the EU countries only. If there is no trade agreement in place with the EU post Brexit, the UK faces the prospect of trading with the EU under WTO rules, implying tariffs on vehicles, pharmaceuticals and most agricultural products. ${ }^{22}$

Second, the 'hard Brexit plus' scenario assumes UK trade relations with the FTA and EPA countries are additionally affected, ending free trade with over 60 more countries. After Brexit, inheriting the EU's various free trade deals with third countries is not automatically guaranteed. Outside the EU, the UK's negotiating position will be weaker and will likely require an offer of more favourable terms of tradefor countries with either existing or prospective trade deals with the EU (see the Appendix Table 7 for the list of EU agreements pending and under negotiation).

Last, with a hard Brexit offering the freedom to strike its own deals with the rest of the world, the 'global Britain' scenario assumes the UK can trade freely with all other countries upon leaving the EU. This might entail a prized trade deal with the US, the UK's biggest trading partner (by exports), as well as trade deals with populous countries such as China and India in line with the UK's recent trends of rising trade shares with emerging and developing countries set against a general decrease in its trade shares with the EU (see the Appendix Table 8).

In practical terms, the three Brexit dummies are modelled by switching the values for the UK bilateral trading relations from 2019 onwards: from one to zero with the EU countries under the 'hard Brexit' scenario; from one to zero with the EU, FTA and EPA countries under the 'hard Brexit plus' scenario; and from zero to one with all other countries (nearly 100 countries in the sample) under the 'global Britain' scenario, where the 'global Britain' scenario inherently assumes a hard Brexit plus scenario. Calculating the trade effects of the three alternative counterfactual scenarios amounts to comparing the predicted values of each scenario with the predicted values of the benchmark 'no Brexit' scenario. ${ }^{23}$

\footnotetext{
${ }^{22}$ After Brexit, setting new terms of its own with the WTO would be an arduous process involving approval by the other 163 WTO members. As an alternative, all tariffs and quotas in place under existing terms of EU membership could be eliminated, but would be opposed by various sectors including farming and manufacturing.

${ }^{23}$ As the predicted values generated from the benchmark and Brexit scenarios are derived from the WEO's data projections, the effects of the various Brexit scenarios intrinsically depend on the data projections and their associated assumptions.
} 
Table 4 shows the predicted counterfactual values associated with the three Brexit scenarios and the corresponding percentage change in bilateral imports, averaged over the post Brexit years, 1919-2022, and across four country groups (the EU member countries; countries partaking in various trade related agreements including customs unions, FTAs, association agreements and stabilisation agreements; countries belonging to trade and development EPAs; as well as countries for which there is no trade agreement with the EU i.e. the rest of the world (ROW). Bilateral relations with all countries in the sample are shown in the last column. Panel A shows the estimates for bilateral UK relations and Panel B shows the corresponding estimates for bilateral EU relations.

Under all three scenarios, the findings suggest the UK's trade with the EU would decline by up to one-third (column 1). Under the hard Brexit plus and global Britain scenarios, trade with the FTA and EPA country groups would fall by a similar magnitude (columns 2 and 3). A hard Brexit, however, brings opportunities to trade with the rest of the world, which would rise by nearly a half (column 4). In fact, UK bilateral trade in aggregate could increase by over 5\% (column 5), implying the benefits of a global Britain strategy would go a long way towards offsetting the losses of a hard Brexit $(-6.02 \%)$, although falling far short of lost trade with all countries for which it currently has a trade deal $(-12.80 \%)$. From the EU's perspective, only minor percentage changes in bilateral trade are predicted under all three scenarios (Panel B), suggesting an asymmetry of effect.

The findings are broadly consistent with the empirical Brexit literature, which use different data sources (such as the WIOD); different time frames (usually conducted in advance of the actual withdrawal date); and different methodologies (such as the fixed effects approach by HM Treasury 2016 or Anderson et al.'s (2015) approach to estimating general equilibrium trade policy effects used by Brakman et al. 2018 and Oberhofer and Pfaffermayr 2018). The estimates for the global Britain scenario, however, are somewhat higher, partly reflecting the broader country coverage. Indeed, the higher values are borne out by a direct comparison between the counterfactual predictions generated from the gravity model using 2SLS with time and country fixed effects and the corresponding values using least squares with time and country fixed effects, shown in Table 5. Nevertheless, the main conclusions ensue. ${ }^{24}$ The decision to exit the EU rests with the UK and the consequences of that decision will be felt mainly by the UK.

Some caveats are in order. First, the parameter estimates for the EU trade related agreements and the associated counterfactual Brexit scenarios capture static trade effects only. In addition, the counterfactual trade policy predictions are only of short run duration. Ideally, an analysis of the trade consequences of Brexit would extend beyond the 2019-2022 period to match the UK's long term membership of the EU since 1973.

Kierzenkowski et al. (2016) have previously suggested that the Brexit 'shock' could be transmitted through several channels over time, In the near term, bilateral trade

\footnotetext{
${ }^{24}$ A comparison of the results for the benchmark specification using the full sample period (Table 2, column 1) with the corresponding results using actual data only (Table 3, column 1) also shows somewhat higher EIA dummy coefficients using the latter, implying the counterfactual predictions are also likely to be higher.
} 
Table 4 Counterfactual predictions (US\$ million)

\begin{tabular}{|c|c|c|c|c|c|}
\hline Panel A & $\begin{array}{l}(1) \\
U K-E U\end{array}$ & $\begin{array}{l}\text { (2) } \\
\text { UK-FTA }\end{array}$ & $\begin{array}{l}\text { (3) } \\
\text { UK-EPA }\end{array}$ & $\begin{array}{l}\text { (4) } \\
\mathrm{UK}-\mathrm{ROW}\end{array}$ & $\begin{array}{l}(5) \\
\text { UK-All }\end{array}$ \\
\hline \multicolumn{6}{|l|}{ No Brexit } \\
\hline WEO forecast value & 14,762 & 3226 & 501 & 2820 & 4354 \\
\hline Predicted value & 27,715 & 2484 & 738 & 2913 & 9040 \\
\hline \multicolumn{6}{|c|}{ Predicted counterfactual value } \\
\hline Hard Brexit & 19,757 & 2531 & 745 & 2994 & 7039 \\
\hline Hard Brexit plus & 20,339 & 1778 & 522 & 3063 & 7054 \\
\hline Global Britain & 19,620 & 1716 & 504 & 4305 & 7434 \\
\hline \multicolumn{6}{|l|}{ Percentage change } \\
\hline Hard Brexit & $-29.83 \%$ & $1.77 \%$ & $1.17 \%$ & $2.61 \%$ & $-6.02 \%$ \\
\hline Hard Brexit plus & $-27.81 \%$ & $-28.50 \%$ & $-28.76 \%$ & $4.90 \%$ & $-12.80 \%$ \\
\hline Global Britain & $-30.41 \%$ & $-31.07 \%$ & $-31.20 \%$ & $47.12 \%$ & $5.48 \%$ \\
\hline Panel B & EU-EU & EU-FTA & EU-EPA & EU-ROW & EU-All \\
\hline \multicolumn{6}{|l|}{ No Brexit } \\
\hline WEO forecast value & 8147 & 994 & 90 & 941 & 1927 \\
\hline Predicted value & 17,862 & 1407 & 219 & 1225 & 5464 \\
\hline \multicolumn{6}{|c|}{ Predicted counterfactual value } \\
\hline Hard Brexit & 17,906 & 1415 & 219 & 1242 & 5485 \\
\hline Hard Brexit plus & 18,001 & 1428 & 220 & 1251 & 5516 \\
\hline Global Britain & 17,891 & 1418 & 218 & 1234 & 5478 \\
\hline \multicolumn{6}{|l|}{ Percentage change } \\
\hline Hard Brexit & $0.12 \%$ & $0.02 \%$ & $-0.10 \%$ & $1.10 \%$ & $0.58 \%$ \\
\hline Hard Brexit plus & $0.56 \%$ & $0.09 \%$ & $0.46 \%$ & $1.69 \%$ & $1.18 \%$ \\
\hline Global Britain & $-0.17 \%$ & $0.03 \%$ & $0.29 \%$ & $0.32 \%$ & $0.18 \%$ \\
\hline
\end{tabular}

The counterfactual predictions, estimated for a panel of EU-ROW imports over the period 1980-2022 using 2SLS with time and country fixed effects, are compared with the predicted values associated with the no Brexit scenario and averaged over the 1919-2022 period and across the country groups

would decline as the loss of unrestricted access to the Single Market and preferential access to third countries would entail higher tariffs and barriers. Heightened economic uncertainty would reduce confidence, potentially affecting the cost and availability of finance and the financing of the current account deficit via changes in capital flows. Migration incentives would also be affected with restrictions on the free movement of labour from the EU and a weaker UK economy after exit. By 2020, these effects could shave off $3 \%$ of UK output (equivalent to GB£2200 per household).

In the longer term, structural changes could mean lower business investment brought about by lower foreign direct investment (FDI) inflows from the EU. Less trade and investment would mean less openness and innovation and hence technical progress and productivity would be reduced. Less immigration could also affect the pool of skills as well as long term growth. By 2030, UK output could be more than 5\% smaller as a non EU member (i.e. between GB£3200 and GB£5000 per household depending on the central or pessimistic scenario). In a similar vein, Van 
Table 5 Counterfactual predictions (US\$ million)

\begin{tabular}{|c|c|c|c|c|c|c|}
\hline \multicolumn{2}{|l|}{ Panel A } & $\begin{array}{l}\text { (1) } \\
\mathrm{UK}-\mathrm{EU}\end{array}$ & $\begin{array}{l}(2) \\
\text { UK-FTA }\end{array}$ & $\begin{array}{l}\text { (3) } \\
\text { UK-EPA }\end{array}$ & $\begin{array}{l}\text { (4) } \\
\text { UK-ROW }\end{array}$ & $\begin{array}{l}\text { (5) } \\
\text { UK-All }\end{array}$ \\
\hline \multicolumn{7}{|l|}{ No Brexit } \\
\hline \multicolumn{2}{|c|}{ WEO forecast value } & 14,762 & 3226 & 501 & 2820 & 4354 \\
\hline \multicolumn{2}{|l|}{ Predicted value } & 28,087 & 2448 & 707 & 2981 & 9158 \\
\hline \multicolumn{7}{|c|}{ Predicted counterfactual value } \\
\hline \multicolumn{2}{|l|}{ Hard Brexit } & 21,294 & 2487 & 715 & 3043 & 7447 \\
\hline \multicolumn{2}{|l|}{ Hard Brexit plus } & 22,010 & 1877 & 536 & 3105 & 7525 \\
\hline \multicolumn{2}{|l|}{ Global Britain } & 21,762 & 1848 & 526 & 4021 & 7881 \\
\hline \multicolumn{7}{|l|}{ Percentage change } \\
\hline \multicolumn{2}{|l|}{ Hard Brexit } & $-25.10 \%$ & $1.60 \%$ & $1.16 \%$ & $1.98 \%$ & $-5.13 \%$ \\
\hline \multicolumn{2}{|l|}{ Hard Brexit plus } & $-22.77 \%$ & $-23.41 \%$ & $-23.68 \%$ & $3.93 \%$ & $-10.55 \%$ \\
\hline \multicolumn{2}{|l|}{ Global Britain } & $-23.85 \%$ & $-24.73 \%$ & $-25.00 \%$ & $34.25 \%$ & $2.92 \%$ \\
\hline Panel B & \multicolumn{2}{|l|}{ EU-EU } & EU-FTA & EU-EPA & EU-ROW & EU-All \\
\hline \multicolumn{7}{|l|}{ No Brexit } \\
\hline $\begin{array}{l}\text { WEO forecast } \\
\text { value }\end{array}$ & \multicolumn{2}{|l|}{8147} & 994 & 90 & 941 & 1927 \\
\hline Predicted value & \multicolumn{2}{|l|}{18,106} & 1396 & 210 & 1252 & 5537 \\
\hline \multicolumn{7}{|c|}{ Predicted counterfactual value } \\
\hline Hard Brexit & \multicolumn{2}{|l|}{18,101} & 1404 & 210 & 1264 & 5543 \\
\hline Hard Brexit plus & \multicolumn{2}{|l|}{18,215} & 1413 & 210 & 1274 & 5578 \\
\hline Global Britain & \multicolumn{2}{|l|}{18,173} & 1402 & 207 & 1267 & 5562 \\
\hline \multicolumn{7}{|l|}{$\begin{array}{c}\text { Percentage } \\
\text { change }\end{array}$} \\
\hline Hard Brexit & \multicolumn{2}{|l|}{$0.10 \%$} & $0.36 \%$ & $0.15 \%$ & $0.77 \%$ & $0.47 \%$ \\
\hline Hard Brexit plus & \multicolumn{2}{|l|}{$0.40 \%$} & $0.66 \%$ & $0.49 \%$ & $1.40 \%$ & $0.92 \%$ \\
\hline Global Britain & \multicolumn{2}{|l|}{$-0.28 \%$} & $-0.33 \%$ & $-0.52 \%$ & $0.65 \%$ & $0.12 \%$ \\
\hline
\end{tabular}

The counterfactual predictions, estimated for a panel of EU-ROW imports over the period 1980-2022 using least squares estimation with time and country fixed effects, are compared with the predicted values associated with the no Brexit scenario and averaged over the 1919-2022 period and across the country groups

Reenen (2016) suggests welfare losses of between 1.3 and $2.6 \%$ depending on a soft or hard Brexit scenario, rising to between 6.3 and $9.5 \%$ when productivity effects are incorporated in a dynamic model.

Second, there is some uncertainty associated with the predicted values, for example, the gravity model predictions of trade values with the EU are much higher when compared with the WEO forecast values. ${ }^{25}$

\footnotetext{
25 An incomplete set of data are available for the infrastructure variables, implying the predicted values for countries with missing infrastructure data - typically smaller countries - cannot be generated. The consequence is that the predicted values tend to be higher when compared with the WEO forecast data.
} 
Third, the global Britain strategy is over optimistic and unrealistic; forging new trade deals with so many countries in such a short term horizon is not possible. Given their complexity, negotiating trade deals typically involves considerable time (to agree deep rather than shallow deals) ${ }^{26}$; personnel and expertise (largely absent in the UK until recently owing to its long term membership of the EU without any need to agree trade deals for itself); as well as trade offs (divergent rules between the US and the EU on genetically modified foods, for example, involve a choice between freer trade with the former versus the latter). Furthermore, a no deal outcome with the EU runs the risk that some countries may diversify trade away from the UK and redirect it towards the remaining EU member countries.

Overall, the numbers suggest that retaining free trade deals with the EU and third countries is of greater priority than their forfeiture in favour of potential free trade with the rest of the world. Afterall, about half of the UK's trade is conducted with its EU neighbouring countries ${ }^{27}$ with seven of its top ten trading partners belonging to the EU (see Figs. 1 and 2).

In the post Brexit era, the UK's trade strategy will involve prioritising trade deals with some countries over others. The natural starting point is to agree a trade deal with the EU- the block of countries representing the UK's largest and nearest trading partners-to ensure continued free trade and prevent the imposition of tariffs, barriers and checks on goods arriving into the UK. Rolling over existing trade deals with the EU, agreed while the UK was still a member, is also of paramount importance to avoid disruption for firms. ${ }^{28}$ Next up are trade deals with large countries such as the US, China, India and Japan that would provide British exporters with access to large foreign markets and therefore, would likely yield greatest benefits from the UK's perspective. Commonwealth countries-a group of 53 countries with current or historical colonial linkages to Britain-including Australia, Canada and New Zealand are also on the list of high priority trade deals. ${ }^{29}$

\footnotetext{
${ }^{26}$ The depth of trade agreements can vary according to provisions relating to tariffs, services liberalisation, investment rules, standards, public procurement, competition, intellectual property rights and other measures capturing varying degrees of trade liberalisation. As part of future work, it would be interesting to also examine the depth of bilateral trade agreements. Bowen et al. (2010), for example, measure the degree of economic integration across a range of RTAs. For the entire set of PTAs in force and notified to the WTO, Hofmann et al. (2019) evaluate the changing scope of PTAs over time. Using the content of trade agreements to build a measure of depth based on the number of provisions covered by the agreement, Mulabdic et al. (2017) assess UK EU trade relations.

${ }^{27}$ For the year 2016, over 50 per cent of the UK's imports come from the EU and over 47 per cent of its exports go to the EU (trade shares as a percentage of world total, IMF 2017).

28 As of March 2020, 19 trade deals (Andean Community, CARIFORUM, Central America, Chile, Eastern and Southern Africa, Faroe Islands, Georgia, Israel, Jordan, Kosovo, Lebanon, Liechtenstein, Morocco, Pacific states, Palestine, SADC, South Korea, Switzerland and Tunisia) have been rolled over and are expected to take effect at the end of the transition period.

${ }^{29}$ Shared beliefs in an international rules based system for trade and investment make comprehensive FTAs more likely with some countries. For example, negotiating trade deals with Canada and Japan (which already have trade agreements with the EU) or Australia and New Zealand (which are currently in negotiations with the EU) are likely to be less difficult when compared with China and India. The UK will also have to overcome challenges that have led to the suspension of EU trade talks with India and the US (see the Appendix Table 7). Rather than aiming to agree on a full scale FTA, one alternative might involve liberalising economic sectors that matter for the UK (eg financial services) without jeopardising other sensitive sectors (eg food standards in the agricultural sector or drugs prices in the health sector).
} 


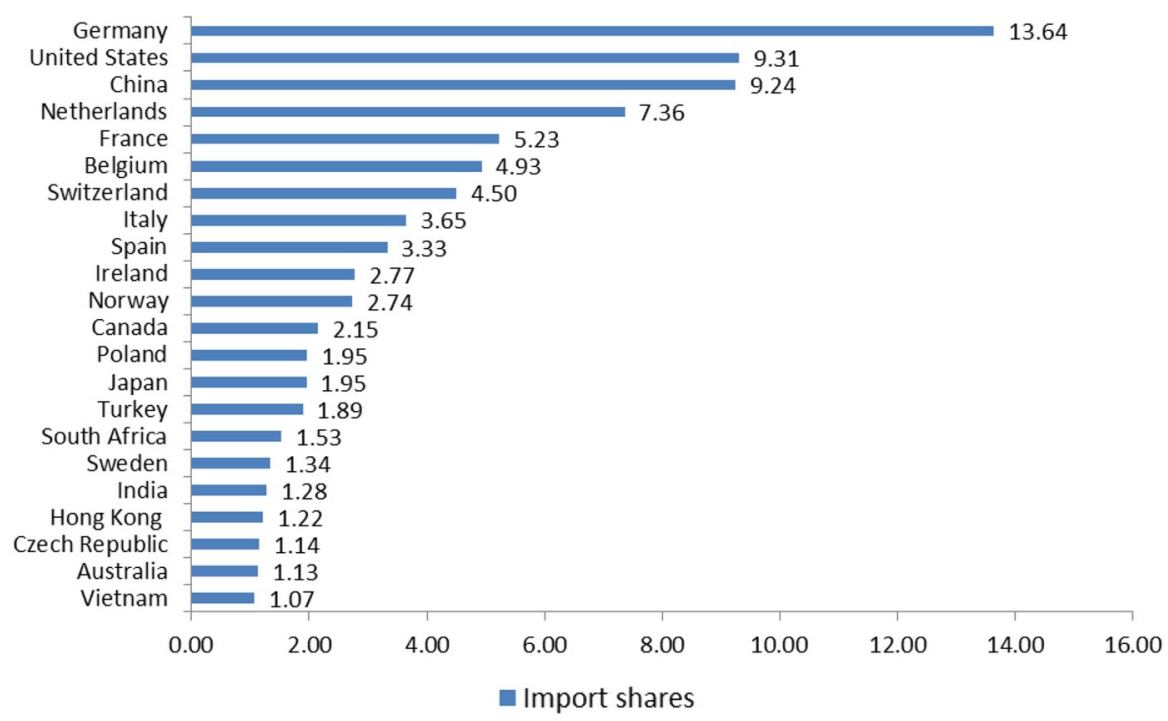

Fig. 1 UK's most important trading partner countries, 2016 (Import shares, \% World). Source: Direction of Trade Statistics, International Monetary Fund

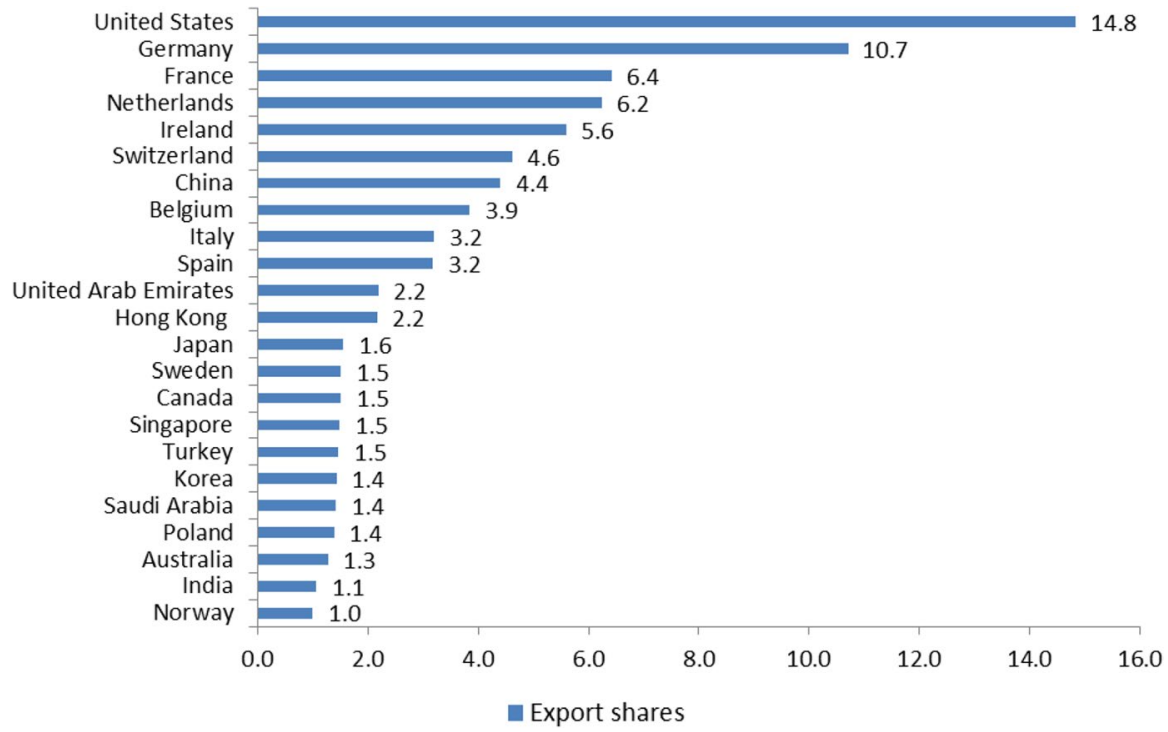

Fig. 2 UK's most important trading partner countries, 2016 (Export shares, \% World). Source: Direction of Trade Statistics, International Monetary Fund 


\section{Conclusions}

Using the gravity model for a panel of bilateral imports between the EU15 and the rest of the world over the 1960-2022 period, the trade effects of EU economic integration agreements, their evolution over time and the related counterfactual Brexit trade policy scenarios are assessed. In distinguishing between the types of arrangements with the EU, opposing coefficient signs are found: positive for EU membership and the FTAs, but negative for the regional EPAs. The mixed results can largely be explained in terms of the degree of liberalisation and the concomitant reduction of tariff and non tariff barriers.

Mapping the evolution of the trade effects of EU trade related agreements over five subperiods capturing different eras of major global shocks, the results suggest the positive coefficients of EU and FTA membership tend to diminish over time, implying earlier membership of EIAs came with greater trade benefits associated with the 'four freedoms' of the Single Market. The effects of EIAs are subdued in the subperiod since the global financial crisis and the debt crisis in Europe while the forecast subperiod suggests a rebound in the trade effect of EU membership.

Finally, in generating the predicted values for the trade effects of three alternative counterfactual Brexit scenarios (hard Brexit, hard Brexit plus, global Britain), the findings suggest the UK's trade with all three country groups (the EU, the FTAs and regional EPAs) would decline substantially, approximately by one-third. At the same time, trade with the rest of the world would rise by nearly a half. In aggregate, UK bilateral trade with all countries would decline by $6 \%$ and $13 \%$ under the hard Brexit and the hard Brexit plus scenarios respectively, but these losses would be partially offset by the global Britain strategy (5\%). From the EU's perspective, only minor percentage changes in bilateral trade are predicted under all three scenarios, suggesting an asymmetry of effect.

Of course, the scenario outcomes depend intrinsically on the economic growth projections, which can change as the full consequences of Brexit become apparent and as economic conditions evolve. The results for the global Britain strategy also come with major caveats. What is clear is that a clean break with the EU's single market and customs union is made difficult by more than 45 years of EU membership and intertwined regulatory and institutional practices. In the end, the choice comes down to the degree to which Britain aligns itself with the EU; closer to the EU akin to Norway plus (adding a customs union to membership of the single market); farther away based on the EU's deal with Canada; or something in between modelled on the EU's deep and comprehensive FTA with Ukraine, which would allow access to the single market, allow new deals with third countries and end free movement of people. There is a large range of existing trade deals from which a template can be drawn!

\section{Appendix}

See Tables 6, 7 and 8 . 


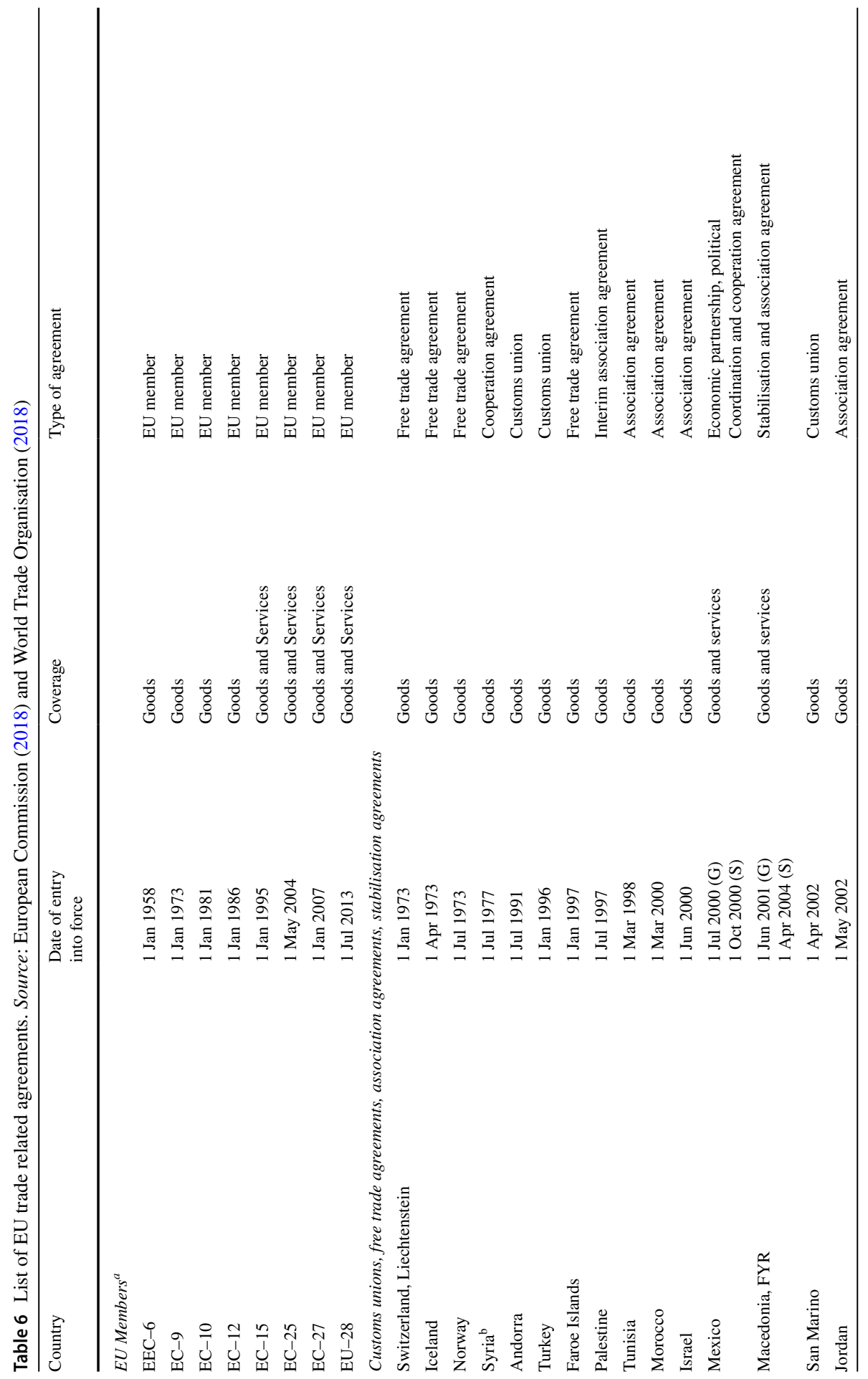




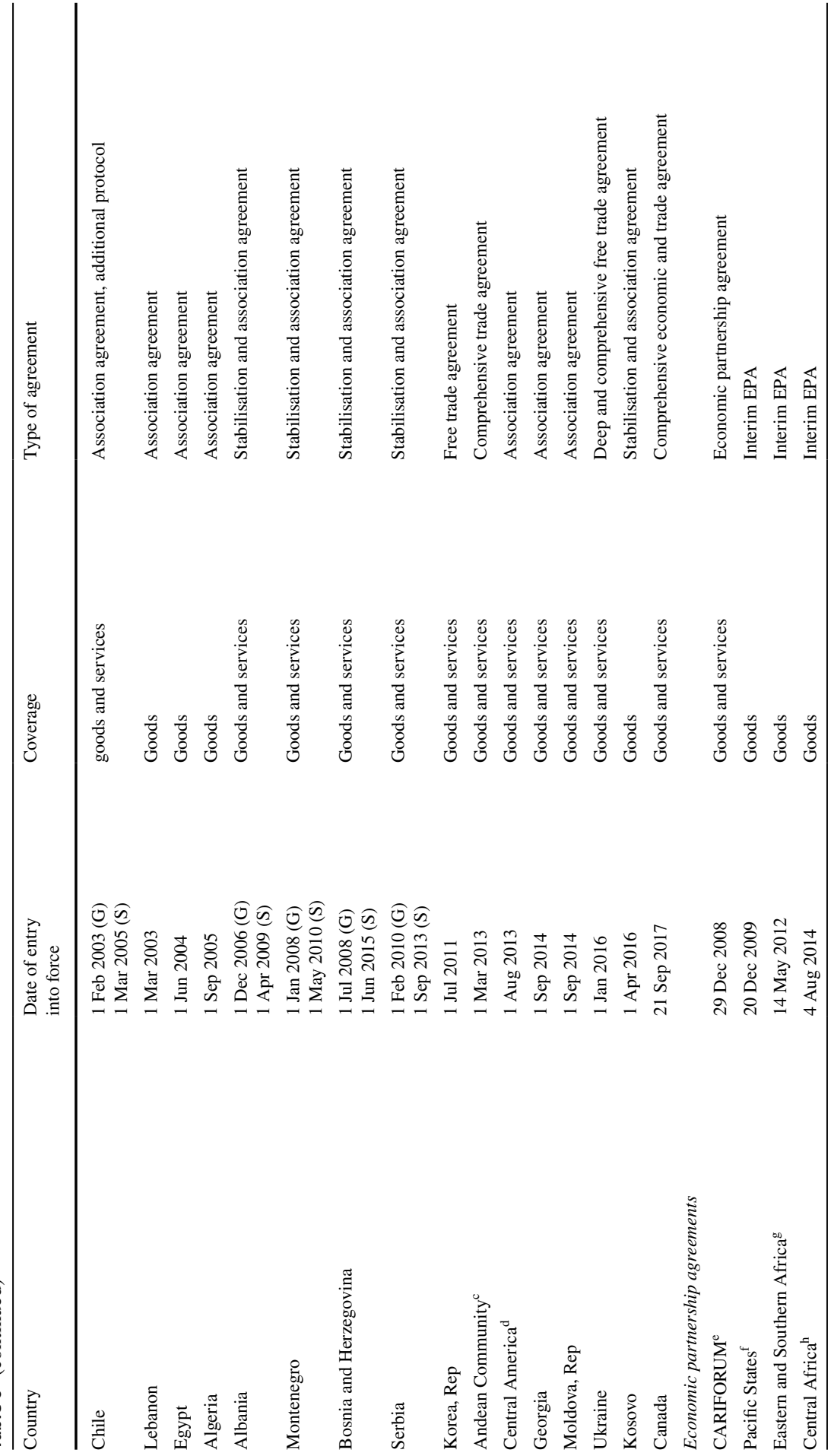




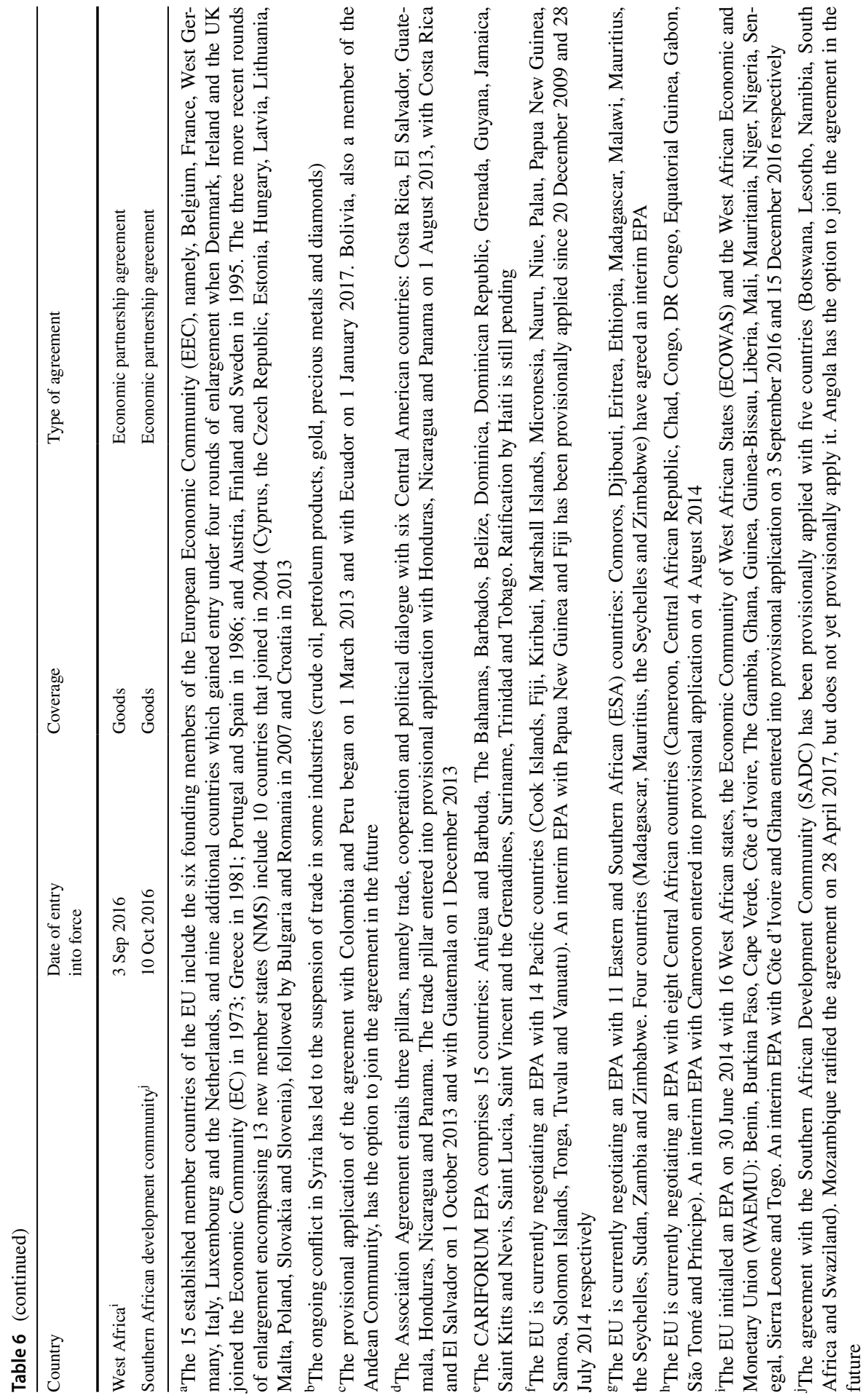


Table 7 List of EU trade related agreements pending, under negotiation and suspended. Source: European Commission (2018) and World Trade Organisation (2018)

\begin{tabular}{|c|c|}
\hline Country & Agreement \\
\hline \multicolumn{2}{|l|}{ Agreements pending } \\
\hline Singapore $^{\mathrm{a}}$ & Free trade agreement \\
\hline Vietnam $^{\mathrm{b}}$ & Free trade agreement \\
\hline $\mathrm{Japan}^{\mathrm{c}}$ & Economic partnership agreement \\
\hline \multicolumn{2}{|l|}{ Agreements under negotiation } \\
\hline East African Community ${ }^{\mathrm{d}}$ & Economic partnership agreement \\
\hline Mercosur ${ }^{\mathrm{e}}$ & Association agreement \\
\hline Philippines $^{\mathrm{f}}$ & Free trade agreement \\
\hline Indonesia $^{\mathrm{g}}$ & Free trade agreement \\
\hline Australia $^{\mathrm{h}}$ & Free trade agreement \\
\hline New Zealand ${ }^{\mathrm{i}}$ & Free trade agreement \\
\hline \multicolumn{2}{|l|}{ Agreements suspended } \\
\hline Gulf Cooperation Council ${ }^{\mathrm{j}}$ & Free trade agreement \\
\hline $\operatorname{India}^{\mathrm{k}}$ & Free trade agreement \\
\hline Malaysia $^{1}$ & Free trade agreement \\
\hline Thailand $^{\mathrm{m}}$ & Free trade agreement \\
\hline United States $^{\mathrm{n}}$ & Transatlantic trade and investment partnership \\
\hline
\end{tabular}

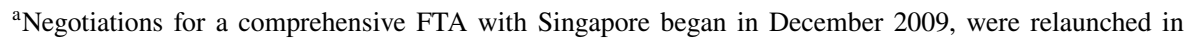
March 2010 and were concluded on 17 October 2014. The Agreement is awaiting ratification

${ }^{\mathrm{b}}$ Negotiations for a comprehensive FTA with Vietnam began in October 2012 and were concluded on 2 December 2015. The Agreement is awaiting approval

${ }^{\mathrm{c}}$ Negotiations for an EPA with Japan began on 25 March 2013; 19 rounds of talks were concluded on 8 December 2017. The treaty is awaiting signature

${ }^{\mathrm{d}}$ On 16 October 2014, the EU initialled an EPA with the East African Community (EAC), comprising five partner states (Burundi, Kenya, Rwanda, Tanzania and Uganda)

${ }^{\text {e}}$ Negotiations for an Association Agreement with the four founding members of Mercosur (Argentina, Brazil, Paraguay and Uruguay) were relaunched in May 2010, were paused in 2012 and resumed in May 2016

${ }^{\mathrm{f}}$ Negotiations for a FTA with the Philippines began on 22 December 2015

${ }^{g}$ Negotiations for a FTA with Indonesia began on 1 September 2016; three rounds have been concluded

${ }^{\mathrm{h}}$ Negotiations for a FTA with Australia were launched in June 2018

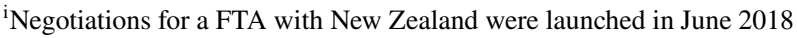

${ }^{\mathrm{j} N e g o t i a t i o n s ~ f o r ~ a ~ F T A ~ w i t h ~ t h e ~ s i x ~ m e m b e r s ~ o f ~ t h e ~ G C C, ~ n a m e l y ~ B a h r a i n, ~ K u w a i t, ~ O m a n, ~ Q a t a r, ~ S a u d i ~}$ Arabia and United Arab Emirates, began in 1990, but were suspended in 2008

${ }^{\mathrm{k}}$ Negotiations for a FTA with India began in 2007, but have stalled since 2012

${ }^{1}$ Negotiations for a FTA with Malaysia began in October 2010, but have stalled after 7 rounds of talks

${ }^{m}$ Negotiations for a comprehensive FTA with Thailand began in May 2013, but have stalled after 4 rounds of negotiations, coinciding with the military takeover of the country in April 2014

${ }^{\mathrm{n}}$ Negotiations for the TTIP with the United States began in 2013, but after 15 rounds of talks, further negotiations were put on hold at the end of 2016 as a new Administration entered Washington 
Table 8 The UK's evolving trade shares (\% of World). Source: Direction of Trade Statistics (2017), International Monetary Fund

\begin{tabular}{|c|c|c|c|c|c|c|}
\hline & \multicolumn{2}{|c|}{ Advanced economies } & \multicolumn{2}{|c|}{ European Union } & \multicolumn{2}{|c|}{$\begin{array}{l}\text { Emerging and developing } \\
\text { countries }\end{array}$} \\
\hline & Import Share & Export Share & Import Share & Export Share & Import Share & Export Share \\
\hline 1950 & 57.64 & 61.11 & 26.23 & 28.00 & 40.64 & 38.73 \\
\hline 1955 & 64.21 & 62.83 & 28.46 & 30.47 & 35.25 & 36.96 \\
\hline 1960 & 65.18 & 64.32 & 30.67 & 30.99 & 34.52 & 35.25 \\
\hline 1965 & 66.59 & 69.46 & 33.84 & 39.06 & 33.11 & 30.05 \\
\hline 1970 & 70.95 & 72.00 & 38.09 & 42.16 & 28.61 & 27.11 \\
\hline 1975 & 70.86 & 68.25 & 45.46 & 42.96 & 27.72 & 30.10 \\
\hline 1980 & 79.95 & 74.23 & 49.87 & 53.37 & 19.75 & 25.12 \\
\hline 1985 & 86.42 & 81.27 & 55.28 & 54.86 & 13.16 & 18.39 \\
\hline 1990 & 88.79 & 84.21 & 58.31 & 58.33 & 10.52 & 14.93 \\
\hline 1995 & 84.22 & 80.93 & 52.82 & 56.07 & 11.95 & 15.20 \\
\hline 2000 & 79.23 & 85.66 & 49.73 & 58.61 & 16.62 & 13.19 \\
\hline 2005 & 71.76 & 80.32 & 51.08 & 55.07 & 21.01 & 16.12 \\
\hline 2010 & 69.11 & 75.80 & 48.02 & 51.36 & 26.07 & 20.33 \\
\hline 2016 & 72.75 & 75.93 & 50.25 & 47.30 & 25.82 & 22.32 \\
\hline
\end{tabular}

\section{References}

Aitken, N. D. (1973). The effect of the EEC and EFTA on European trade: A temporal cross-section analysis. American Economic Review, 63(5), 881-892.

Anderson, J. E. (1979). A theoretical foundation for the gravity equation. American Economic Review, 69(1), 106-116.

Anderson, J. E., Larch, M. \& Yotov, Y. V. (2015). Estimating general equilibrium trade policy effects: GE PPML, CESifo Working Paper Series No. 5592.

Anderson, J. E., \& van Wincoop, E. (2003). Gravity with gravitas: A solution to the border puzzle. American Economic Review, 93(1), 170-192.

Baier, S. L., \& Bergstrand, J. H. (2004). Economic determinants of free trade agreements. Journal of International Economics, 64(1), 29-63.

Baier, S. L., \& Bergstrand, J. H. (2007). Do free trade agreements actually increase members' international trade? Journal of International Economics, 71(1), 72-95.

Baldwin, R. \& Taglioni, D. (2006). Gravity for dummies and dummies for gravity equations, NBER Working Paper No. 12516.

Baltagi, B. H., Egger, P., \& Pfaffermayr, M. (2003). A generalized design for bilateral trade flows models. Economics Letters, 80(3), 391-397.

Bayoumi, T., \& Eichengreen, B. (1998). Is regionalism simply a diversion? Evidence from the evolution of the EC and EFTA. In T. Ito \& A. Krueger (Eds.), Regionalism versus multilateral trade arrangements. Chicago: University Chicago Press.

Bergstrand, J. H. (1989). The generalized gravity equation, monopolistic competition, and the factor-proportions theory in international trade. Review of Economics and Statistics, 71(1), 143-153.

Bergstrand, J. H., Larch, M., \& Yotov, Y. V. (2015). Economic integration agreements, border effects, and distance elasticities in the gravity equation. European Economic Review, 78, 307-327.

Bougheas, S., Demetriades, P. O., \& Morgenroth, E. L. W. (1999). Infrastructure, transport costs and trade. Journal of International Economics, 47(1), 169-189.

Bowen, H. P., Munandar, H., \& Viaene, J. M. (2010). How integrated is the world economy? Review of World Economics, 146(3), 389-414. 
Brakman, S., Garretsen, H., \& Kohl, T. (2018). Consequences of Brexit and options for a 'Global Britain'. Papers in Regional Science, 97(1), 55-72.

Bussière, M., Fidrmuc, J., \& Schnatz, B. (2005). Trade integration of central and eastern European countries: Lessons from a gravity model. Working Paper Series No. 545, European Central Bank.

Carrère, C. (2006). Revisiting the effects of regional trade agreements on trade flows with proper specification of the gravity model. European Economic Review, 50(2), 223-247.

Centre d'études prospectives et d'informations internationales (CEPII, 2018). http://www.cepii.fr/CEPII/ en/bdd_modele/bdd.asp. Retrieved 2018.

Cheng, I. H., \& Wall, H. J. (2005). Controlling for heterogeneity in gravity models of trade and integration. Federal Reserve Bank of St. Louis Review, 87(1), 49-63.

Dhingra, S., Huang, H., Ottaviano, G., Pessoa, J. P., Sampson, T., \& Van Reenen, J. (2017). The costs and benefits of leaving the EU: Trade effects. Economic Policy, 32(92), 651-705.

Douch, M., Edwards, T. H., \& Soegaard, C. (2018). Estimating the trade effects of the Brexit announcement shock. http://ukandeu.ac.uk/estimating-the-trade-effects-of-the-brexit-announcement-shock/.

Egger, P., Larch, M., Staub, K. E., \& Winkelmann, R. (2011). The trade effects of endogenous preferential trade agreements. American Economic Journal: Economic Policy, 3(3), 113-143.

European Commission (1996). Economic Evaluation of the Internal Market, European Economy, No. 4, Luxembourg: Office for the Official Publications of the EC.

European Commission (2017). Europe on the move: An overview of the EU road transport market in 2015. Luxembourg: European Commission.

European Commission (2018). http://ec.europa.eu/trade/policy/countries-and-regions/development/econo mic-partnerships/index_en.htm.

Feenstra, R. C. (2002). Border effects and the gravity equation: Consistent methods for estimation. Scottish Journal of Political Economy, 49(5), 491-506.

Felbermayr, G., Gröschl, J., \& Steininger, M. (2018). Quantifying Brexit: From ex post to ex ante using structural gravity. CESifo Working Paper No. 7357.

Food and Agriculture Organization of the United Nations (2018). https://landportal.org/book/indicator/ fao-21017-6124.

Francois, J., \& Manchin, M. (2013). Institutions, infrastructure, and trade. World Development, 46(1), $165-175$.

Greenaway, D., \& Milner, C. (2002). Regionalism and gravity. Scottish Journal of Political Economy, 49, 574-585.

Gruber, W. H., \& Vernon, R. (1970). The technology factor in a world trade matrix. In R. Vernon (Ed.), The technology factor in international trade (pp. 233-272). New York/London: Columbia University Press.

Head, K., Mayer, T., \& Ries, J. (2010). The erosion of colonial trade linkages after independence. Journal of International Economics, 81(1), 1-14.

Heckscher, E. (1919). The effects of foreign trade on the distribution of income. Ekonomisk Tidskrift, 21, 497-512.

HM Treasury (2016). The long-term economic impact of EU membership and the alternatives. London: HM Government.

Hofmann, C., Osnago, A., \& Ruta, M. (2019). The content of preferential trade agreements. World Trade Review, 18(3), 365-398.

International Monetary Fund (2017). Direction of Trade Statistics (July 2017). UK Data Service. https:// doi.org/10.5257/imf/dots/2017-07.

International Monetary Fund (2018a). World Economic Outlook Database (April 2018). https://www.imf. org/external/pubs/ft/weo/2018/01/weodata/index.aspx.

International Monetary Fund (2018b). World Economic Outlook Report (April 2018), Cyclical upswing, structural change. Washington DC: IMF.

Kee, H. L., \& Nicita, A. (2017). Short-term impact of Brexit on the UK's export of goods. World Bank Policy Research Working Paper No. 8195.

Lake, J., \& Yildiz, H. M. (2016). On the different geographic characteristics of free trade agreements and customs unions. Journal of International Economics, 103, 213-233.

Limão (2016). Preferential trade agreements. NBER Working Paper No. 22138.

Linder, S. B. (1961). An essay on trade and transformation. New York: Wiley.

Magee, C. S. (2003). Endogenous preferential trade agreements: An empirical analysis. The BE Journal of Economic Analysis and Policy, 2(1), 1-19. 
Mátyás, L. (1997). Proper econometric specification of the gravity model. The World Economy, 20(3), 363-368.

Mulabdic, A. Osnago, A., \& Ruta, M. (2017). Deep integration and UK-EU trade relations. World Bank Policy Research Working Paper No. 7947.

Oberhofer, H., \& Pfaffermayr, M. (2018). Estimating the trade and welfare effects of Brexit: A panel data structural gravity model. WU Working Paper No. 259.

Ohlin, B. G. (1933). Interregional and international trade. Cambridge: Harvard University Press.

Kierzenkowski R., Pain, N., Rusticelli, E., \& Zwart, S. (2016). The economic consequences of Brexit: A taxing decision. OECD Economic Policy Paper No. 16.

Persson, M. (2008). Trade facilitation and the EU-ACP economic partnership agreements. Journal of Economic Integration, 23(3), 518-546.

Shea, J. (1997). Instrument relevance in multivariate linear models: A simple measure. Review of Economics and Statistics, 79(2), 348-352.

Stack, M. M. (2009). Regional integration and trade: Controlling for varying degrees of heterogeneity in the gravity model. The World Economy, 32(5), 772-789.

Stack, M. M., Ackrill, R., \& Bliss, (2018). Sugar trade and the role of historical colonial linkages. European Review of Agricultural Economics, 46(1), 79-108.

Van Reenen, J. (2016). Brexit's long-run effects on the UK economy. Brookings Papers on Economic Activity, 2, 367-383.

Vicard, V. (2009). On trade creation and regional trade agreements: does depth matter? Review of World Economics, 145(2), 167-187.

Wooldridge, J. M. (1995). Score diagnostics for linear models estimated by two stage least squares. In G. S. Maddala, P. C. B. Phillips, \& T. N. Srinivasan (Eds.), Advances in econometrics and quantitative economics: Essays in Honor of Professor C. R. Rao. Oxford: Blackwell.

Wooldridge, J. M. (2002). Econometric analysis of cross-section and panel data. Cambridge: MIT Press.

World Bank. (2017). World Development Indicators (September 2017). UK Data Service. https://doi. org/10.5257/wb/wdi/2017-05-03.

World Trade Organisation (2018). https://rtais.wto.org/UI/PublicMaintainRTAHome.aspx.

World Trade Organisation (WTO. (2011). World Trade Report 2011, The WTO and preferential trade agreements: From co-existence to coherence. Geneva: WTO.

Publisher's Note Springer Nature remains neutral with regard to jurisdictional claims in published maps and institutional affiliations. 